\title{
Monitoring and impact mitigation during a 4D seismic survey near a population of gray whales off Sakhalin Island, Russia
}

\author{
Koen Bröker ${ }^{1, *}$, Glenn Gailey ${ }^{2}$, Judy Muir ${ }^{3}$, Roberto Racca ${ }^{4}$ \\ ${ }^{1}$ Shell Global Solutions, Lange Kleiweg 40, 2288GK Rijswijk, The Netherlands \\ ${ }^{2}$ Texas A\&M University, 200 Seawolf Pkwy, Galveston, Texas 77553, USA \\ ${ }^{3}$ LGL Limited environmental research associates, Sidney, British Columbia V8L 3Y8, Canada \\ ${ }^{4}$ JASCO Applied Sciences, 2305-4464 Markham Street, Victoria, British Columbia V8Z 7X8, Canada
}

\begin{abstract}
A 4D seismic survey was conducted in 2010 near the feeding grounds of gray whales off Sakhalin Island, Russia. To minimize disruptions to the whales' feeding activity and enhance understanding of the potential impacts of seismic surveys on gray whales Eschrichtius robustus, an extensive monitoring and mitigation plan (MMP) was developed. Typically, mitigation plans involve observers on seismic vessels to monitor for the presence of marine mammals in an exclusion zone so as to prevent physical injury to the animals. Due to the protected status of western gray whales, an additional protection zone based on a behavioural disturbance threshold of exposure of $156 \mathrm{~dB}$ re $\mu \mathrm{Pa}^{2}$-s per pulse was applied for whales within their feeding habitat defined by the estimated $95 \%$ abundance contour. Real-time radio-transmitting acoustic recorders were deployed along this contour to verify modelled acoustic footprints within the feeding grounds. Shore- and vessel-based observation teams monitored for the presence and activity of whales. A real-time GIS workflow tracking procedure was developed that integrated acoustic and whale positioning data to determine if sound levels at a whales' position within the feeding area exceeded the behavioural threshold, in which case a shut-down of the seismic source was implemented. Additionally, behaviour and distribution surveys were conducted before, during and after the seismic survey to evaluate the effectiveness of the MMP. No large changes in whale movement, respiration, or distribution patterns were observed during the seismic survey. This could be interpreted to mean that the MMP was effective in reducing the sound exposure and behavioural responses of gray whales to seismic sounds.
\end{abstract}

KEY WORDS: Seismic $\cdot$ Mitigation $\cdot$ Western gray whale $\cdot$ Eschrichtius robustus $\cdot$ Sakhalin $\cdot$ Piltun . Sea of Okhotsk $\cdot$ Anthropogenic disturbance

\section{INTRODUCTION}

Anthropogenic sound can have physiological and behavioural impacts on marine mammals, as well as affect their ability to communicate, navigate and forage (Richardson et al. 1995, Nowacek et al. 2007, Southall et al. 2007). Furthermore, certain anthropogenic sound sources have the ability to cause stress, or, under specific conditions, even injury to the auditory system (Southall et al. 2007). Seismic

\footnotetext{
*Corresponding author: koen.broker@shell.com
}

surveys can be an important anthropogenic contributor to the marine soundscape due to the number of surveys conducted and the high source levels involved. The potential physical and behavioural impacts of seismic sound on marine mammals have been the focus of numerous studies (reviewed in Nowacek et al. 2007, Southall et al. 2007), which have advanced understanding of responses for certain cetacean species (e.g. Malme et al. 1986, 1988, Finneran et al. 2002, Lucke et al. 2009, Blackwell et 
al. 2013, Kastelein et al. 2013, Schlundt et al. 2015). Although the exact impacts of seismic surveys on cetacean auditory systems, behaviour and ultimately population dynamics depend on many factors and are generally not well understood, the need for mitigation measures to prevent adverse effects is broadly accepted. This is particularly true when the sound exposures occur over a prolonged period and/or originate from multiple sources in critical habitat of endangered species.

Sakhalin Energy Investment Company is developing oil and gas reserves from 2 platforms located in the Piltun-Astokh license area on the northeastern Sakhalin shelf, Russian Federation (Fig. 1). One of these platforms is the Molikpaq (hereafter 'PA-A') that began operations in 1999. By 2010, the company needed to characterize changes to the subsurface structure resulting from extraction of hydrocarbons, and this required seismic imaging, whereby downward-directed acoustic pulses emitted in the water



Fig. 1. Piltun feeding area showing the estimated $95 \%$ gray whale (Eschrichtius robustus) abundance contour based on June to July 2005 to 2007 shore-based and vessel survey data, 13 distribution stations, 3 behaviour stations and the 2 Sakhalin Energy offshore platforms (PA-A and PA-B) column are used to probe the sub-bottom layers. These resulting data were considered essential for the efficient positioning of new wells (LGL 2010). The 2010 Piltun-Astokh seismic survey, contracted to DalMorNefteGeofizika (DMNG), provided an accurate replication of a portion of the preproduction dataset that had been acquired in 1997. The 2 datasets combined enabled the mapping of production-related changes in the hydrocarbon-bearing reservoir beneath the seabed. It was necessary that acquisition ${ }^{1}$ conditions and array configuration be identical to the 3D seismic survey conducted in 1997 to allow differential visualization over the fourth dimension of time (hence the terminology, 4D survey). The acquisition area was $170 \mathrm{~km}^{2}$, centered around the PA-A platform. As an energy source, 2 airgun arrays of 2620 cubic inches were used, configured in a flip-flop (alternate firing) mode. The survey was conducted from 17 June to 2 July 2010.

The 4D seismic survey area was situated directly offshore (between 5 and $15 \mathrm{~km}$ ) of the Piltun nearshore feeding grounds of gray whales Eschrichtius robustus. The 'western' gray whale population is listed as a Critically Endangered subpopulation in the IUCN Red List of Threatened Species (Reilly et al. 2008) and as endangered in the Russian Red Book (Anonymous 2001). Recent findings on gray whale migration between the eastern and western North Pacific have led to reviews of stock structure hypotheses, but further studies are required to better understand the genetics and history of what has long been known as the western gray whale (Mate et al. 2011, 2015, Urban et al. 2012, 2013, Weller et al. 2012, Bickham et al. 2013, Cooke et al. 2013, IWC 2014). A population assessment estimated the median non-calf Sakhalin 'population' (i.e. animals regularly found off Sakhalin Island) in 2012 to be 140 whales, with a $3.3 \%$ mean annual population growth rate (Cooke et al. 2013).

The Piltun feeding ground is 1 of 2 known feeding grounds off northeastern Sakhalin, and it extends over a distance of $110 \mathrm{~km}$ between Okha in the north and Chayvo Bay in the south (Fig. 1). Most observations of gray whales have been during

\footnotetext{
${ }^{1}$ Seismic acquisition is a key component of geophysical hydrocarbon exploration; it involves the generation and recording of seismic data using a source, usually airguns, and different receiver configurations, e.g. a string of hydrophones towed behind a seismic vessel. The source generates acoustic vibrations that travel to the sea bottom, pass through strata with different seismic responses and filtering effects, and return to the surface to be recorded.
} 
ice-free months (June to November) within the $20 \mathrm{~m}$ isobath, where they feed on the isopods and amphipods that occur at high densities in this area (Fadeev 2011). Apart from the rich benthic prey biomass (average of 35.2 and $18.5 \mathrm{~g} \mathrm{~m}^{-2}$ for amphipods and isopods, respectively; Fadeev 2011), the Piltun feeding area is of particular importance to nursing/weaning gray whale calves, probably due at least in part to the relatively sheltered and shallow nature of the area (Sychenko 2011). The location or locations of this population's wintering grounds are not well understood, but the whales are clearly migratory; at least some of them migrate from Sakhalin to low-latitude areas along the Baja California Peninsula, Mexico, where early calf rearing and courtship activity occur (Urban et al. 2013, Mate et al. 2015), and others possibly migrate to historical wintering grounds in the South China Sea (Weller et al. 2002). The whales return to the Piltun feeding area in the period from June to July and remain until November. Gray whales display a high degree of site fidelity, with most of the individuals photo-identified off Sakhalin Island being observed there nearly every year (Tyurneva et al. 2013). They largely fast for approximately 6 to 7 mo during the breeding and migration period, relying on stored energy acquired during the foraging period at high latitudes. Most individuals are in sub-optimal body condition upon arrival in the northern feeding grounds (Rice \& Wolman 1971, Tyurneva et al. 2013) but recover their body condition over the course of the feeding season (Bradford et al. 2012, Tyurneva et al. 2013). One conservation concern is that the effects of disturbance caused by increasing industrial activity in and near the Piltun feeding area could impair the whales' ability to restore their body condition. Poor body condition, whether due to natural or anthropogenic causes, is known to affect growth, survival and reproductive health in other marine mammals (e.g. New et al. 2013, 2014).

Apart from the overall loudness of sound generated by the airgun arrays, a main concern associated with seismic sources is that their dominant frequency range $(<200 \mathrm{~Hz})$ overlaps with the optimal auditory sensitivity band of baleen whales (Southall et al. 2007). Controlled exposure experiments that examined responses of migrating and feeding gray whales to seismic survey sounds in the northern Bering Sea (Malme et al. 1986, 1988) found that $50 \%$ of the whales stopped feeding at received sound pulse levels of $173 \mathrm{~dB}$ re $1 \mu \mathrm{Pa}$ root mean square (rms). Approximately $10 \%$ of the animals interrupted feeding at received pulse levels of 163 $\mathrm{dB}$ re $1 \mu \mathrm{Pa}$ rms. Despite the application of mitigation criteria based on these thresholds, behavioural responses and changes in distribution, including changes in swim speed, reorientation rate, distance from shore, blow interval and dive time were observed in gray whales during a 3D seismic survey off Sakhalin in 2001 (Gailey et al. 2007a, Johnson et al. 2007, Yazvenko et al. 2007). Although localized displacement was observed, the whales remained within the feeding area throughout that survey. The long-term and populationlevel effects of such localized displacements on the fitness and reproductive success of gray whales are unknown.

Whereas global and national guidelines exist for mitigating the potential impacts of seismic energy on marine mammals (e.g. JNCC 2010, Nowacek et al. 2013), no guidelines on seismic mitigation measures are prescribed by environmental regulators within Russia. Various countries have adopted different sets of mitigation and monitoring requirements (summarized in Weir \& Dolman 2007). Typically, impacts of seismic activity on marine mammals have been mitigated by defining an exclusion zone around the airgun array at a radius within which physiological damage to the auditory system can occur. Marine mammal observers (MMOs) monitor this exclusion zone for the presence of marine mammals as the airguns gradually rampup to full-power prior to the start of seismic acquisition. It is assumed that marine mammals move away from the seismic vessel as the generated sound levels gradually increase (Weir \& Dolman 2007). These measures, however, only mitigate the risk of physiological damage to animals and do not address behavioural responses, masking, or increased stress levels which can occur at lower sound exposure levels (reviewed in Nowacek et al. 2007, Southall et al. 2007). The 2010 Piltun-Astokh Marine Mammal Monitoring and Mitigation Plan (MMP) went beyond common mitigation measures by including a real-time monitoring element to mitigate behavioural impacts through the application of an acoustic threshold and criteria for aberrant behaviour, i.e. indicators of stress/avoidance.

The objectives of the MMP for the 2010 PiltunAstokh 4D survey were 2-fold: (1) to prescribe multiple measures aimed at minimizing physical and behavioural effects of seismic acquisition on gray whales and (2) to augment the available data on the effects of seismic sound on gray whale behaviour, abundance and distribution. In development of the 
MMP, the following international guidelines and criteria were considered:

- Joint Nature Conservation Committee guidelines for minimizing the risk of injury and disturbance to marine mammals from seismic surveys. Guidelines developed by the United Kingdom that have been applied informally elsewhere in Europe and Africa (JNCC 2010).

- High Energy Seismic Survey Review Process and Interim Operational Guidelines for Marine Surveys Offshore Southern California (HESS 1999).

- United States Minerals Management Service Guidelines on Implementation of Seismic Survey Mitigation Measures and Protected Species Observer Program in the Gulf of Mexico (MMS 2007).

- Guidelines/Recommendations as applied in Australia (Australian Government, Department of the Environment, Water, Heritage and the Arts 2008)

- Southall et al. (2007) criteria for injury and behavioural responses for marine mammals.

The mitigation and monitoring strategy used during a 3D seismic survey by Exxon Neftegaz Limited (ENL) in 2001 (Johnson et al. 2007) directly adjacent to the Piltun feeding ground was used as a foundation for further development of the strategy for the 2010 Piltun-Astokh 4D survey. Specialists under contract to Sakhalin Energy Investment Company collaborated with the Western Gray Whale Advisory Panel (WGWAP), an advisory panel of independent scientists convened by the IUCN, in a Seismic Survey Task Force (SSTF) to develop the MMP. This was an intense process that took several workshops and meetings, beginning with a workshop in June 2007 and with the MMP details finally being agreed upon in April 2010; the relevant reports can be found at https://www.iucn.org/wgwap/wgwap/. A description of the overall process to develop the MMP, generalized to provide a broad approach to minimizing disturbance to wildlife from seismic surveys, is given by Nowacek et al. (2013).

This paper summarizes the mitigation and monitoring program designed to minimize the sound exposure impacts of the 2010 Piltun-Ashtokh seismic survey on gray whales and describes its execution during the seismic survey. From a broader perspective, we provide insights intended to improve management of the acoustic impacts of seismic survey operations on cetaceans in general. Detailed analyses of observations on the behaviour and distribution of gray whales are summarized in Gailey et al. (in press) and Muir et al. (in press a,b). A detailed overview of the acoustic monitoring conducted during this survey is outlined in Racca et al. (in press) and Rutenko et al. (2012a).

\section{DEVELOPMENT OF THE MMP}

\section{General overview of the MMP project area and set-up}

A primary objective of this MMP was not only to prevent permanent or temporary threshold shifts in gray whale hearing, but also to minimize adverse behavioural responses by gray whales on near-shore feeding grounds. Given the migratory nature of the whales into and out of their summer feeding grounds, we began with the premise that the most effective mitigation measure was to try to conduct the survey as early in the season as possible given the environmental conditions, i.e. before most of the whales arrived on the feeding grounds off Sakhalin Island.

We estimated the Piltun feeding area boundary using data collected by shore-based and vessel surveys from June to July in 2005, 2006 and 2007 (J. Muir et al. in press c). An acoustic perimeter monitoring line (PML) was defined as a segment of this boundary spanning the length of the seismic survey area, and this line was used in monitoring sound levels at the edge of the feeding grounds (Fig. 2). After a thorough review of the available literature, which is limited, we eventually based our acoustic threshold levels on the work of Malme et al. (1986), who found that $10 \%$ of gray whales in the northern Bering Sea interrupted feeding when exposed to a received sound level of $163 \mathrm{~dB} 1 \mu \mathrm{Pa}$ rms. We applied an equivalent per-pulse sound exposure level of $156 \mathrm{~dB}$ re $\mu \mathrm{Pa}^{2}$-s (henceforth abbreviated to $156 \mathrm{~dB}$ SEL) as a behavioural response threshold. The $156 \mathrm{~dB}$ SEL threshold was computed from estimation of seismic survey pulse duration at the appropriate propagation range (Racca et al. in press). The use of SEL as the target metric provided much greater stability than rms values in both modelled and measured pulse levels, thus enabling a more reliable comparison between the 2 in the field (Racca et al. in press).

The mitigation plan for the 2001 ENL Odoptu 3D seismic survey had used the same behavioural mitigation threshold albeit expressed in terms of the rms sound pressure metric. This plan used $20 \mathrm{~m}$ isobaths as a proxy for the Piltun feeding area boundary and created a $4 \mathrm{~km}$ buffer zone, known as 'Area A', seaward of the boundary (Johnson et al. 2007). The operating assumption was that acquiring seismic lines within Area A would generate sound levels on the feeding grounds exceeding the behavioural threshold of $163 \mathrm{~dB}$ re $1 \mu \mathrm{Pa}$ rms; additional mitigation measures were therefore applied to those lines, such as shutting down when whales were observed in the 


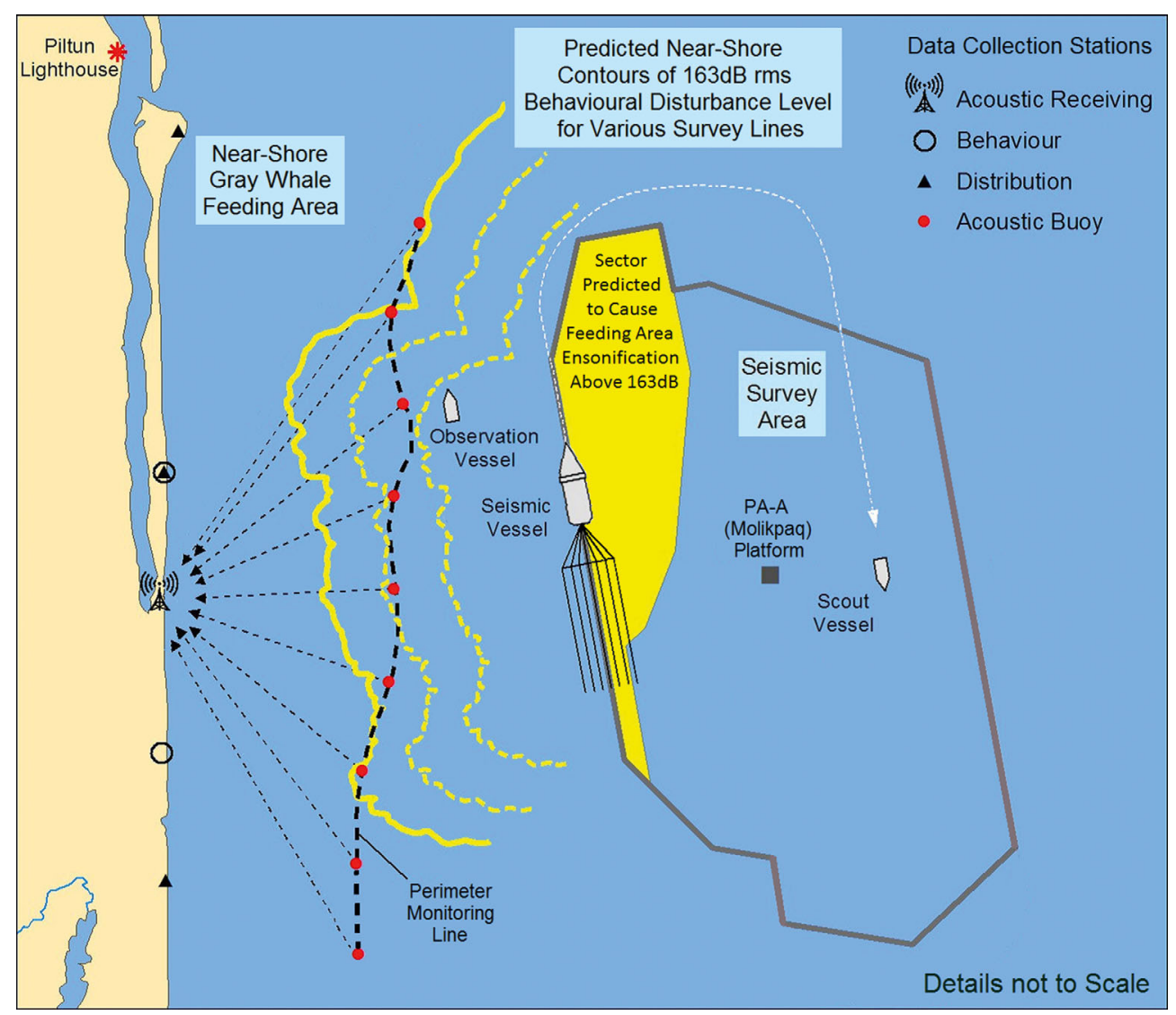

Fig. 2. Schematic depicting the survey layout, including varying acoustic contours (not accurate representations) depending on line number and propagation conditions in the area. Received acoustic levels at the perimeter monitoring line were monitored continuously via a real-time link with the receiving station located at the southern part of the Piltun lagoon (adapted from Nowacek et al. 2013, used with permission)

buffer zone and restricting seismic operations in Area A to daylight hours and periods of good visibility. A $1 \mathrm{~km}$ safety or exclusion zone surrounding the seismic vessel was also applied. A shut-down of the seismic source was ordered if gray whales were observed within this area during acquisition to prevent injury to the hearing system.

We developed these concepts to implement behavioural mitigation in our MMP by identifying seismic lines, termed 'A-lines', as those that could ensonify the delineated feeding grounds at sound levels greater than the $156 \mathrm{~dB}$ SEL behavioural threshold, and by restricting acquisition of these lines to daylight hours and good visibility conditions. We also used the concept of a 'feeding buffer zone', but, in contrast to the static 'feeding buffer zone' applied in the 2001 Odoptu 3D seismic survey, we allowed this behavioural protection buffer, or 'A-zone', to have a dynamic size and shape that was determined by the seismic line actually being acquired and by the prevailing propagation conditions. We defined this A- zone for an individual line as the overlap between the $156 \mathrm{~dB}$ SEL isopleth generated by the seismic vessel when sailing that line and the estimated boundary of the feeding grounds (Fig. 2). The A-zone for an A-line was monitored during acquisition of that line by shore- and vessel-based teams. Mitigation measures specific to A-lines were implemented such as shut-down of the seismic source if gray whales were observed in an A-zone during acquisition. The remaining seismic lines at greater distances from the feeding grounds were called 'B-lines.' Less restrictive mitigation measures were applied to Blines because it was assumed that their acquisition would not result in exposure of animals in the feeding area to sound levels exceeding $156 \mathrm{~dB}$ SEL.

\section{Creation of A-zones and designation of A-lines}

An acoustic envelope was developed for each seismic line based on acoustic propagation modelling 
using environmental parameters thought to prevail at the time of the survey (termed default or 'base' conditions). The Airgun Array Source Model (MacGillivray 2006) was used to generate the close-range directional acoustic footprint for the specific airgun array configuration to be deployed during the survey. The obtained directional levels served as input to the acoustic propagation model 'Marine Operations Noise Mode' (MONM), an extension of the parabolic equation code RAM (Collins et al. 1996), to generate long-range sound level contours for several 10s of source points along each seismic survey line. The shoreward envelope (maximum extent) of the individual contours for the $156 \mathrm{~dB}$ SEL behavioural threshold, maximized over depth, defined the acoustic envelope for that seismic line.

Each acoustic envelope was projected in a Geographic Information System (GIS) to determine if that line's $156 \mathrm{~dB}$ SEL contour overlapped with the feeding area boundary (Fig. 2), thus resulting in an A-zone. This projection was called a 'base case'. Since the propagation conditions during the survey could be different from the default base case and vary over the survey duration, a library of $156 \mathrm{~dB}$ SEL acoustic envelopes corresponding to different propagation regimes and sound level adjustments was generated before the field season for each seismic line. In other words, in addition to the default propagation regime, model scenarios corresponding to low and high sound propagation regimes and level offsets in $1 \mathrm{~dB}$ increments, ranging from -5 to $+5 \mathrm{~dB}$, were pre-computed and stored. A propagation regime and a sound level offset were jointly referred to as a 'model case'; a subset of the 33 possible model cases for a single seismic line is shown in Fig. 3. Fig. 4 shows 3 model cases for the closest shoreward line of the seismic survey and illustrates how the A-zone boundary could be expected to vary according to propagation conditions within the range of feasible cases considered in the modelling. The 12 westernmost lines, out of the total of 35 seismic lines, resulted in A-zones under default conditions and were therefore classified as A-lines.

A-lines were acquired in a south-north direction, and B-lines, in a north-south direction. This was determined by the direction of the line as acquired in 1997, i.e. this was unrelated to the 2010 classification of an A-versus B-line. The relative orientation of the A-lines to the feeding area boundary meant that the seismic vessel's distance to the feeding area decreased as acquisition progressed. Thus, depending on the propagation conditions, the seismic array might not ensonify the feeding grounds with sound levels >156 dB SEL, i.e. result in an A-zone, over the

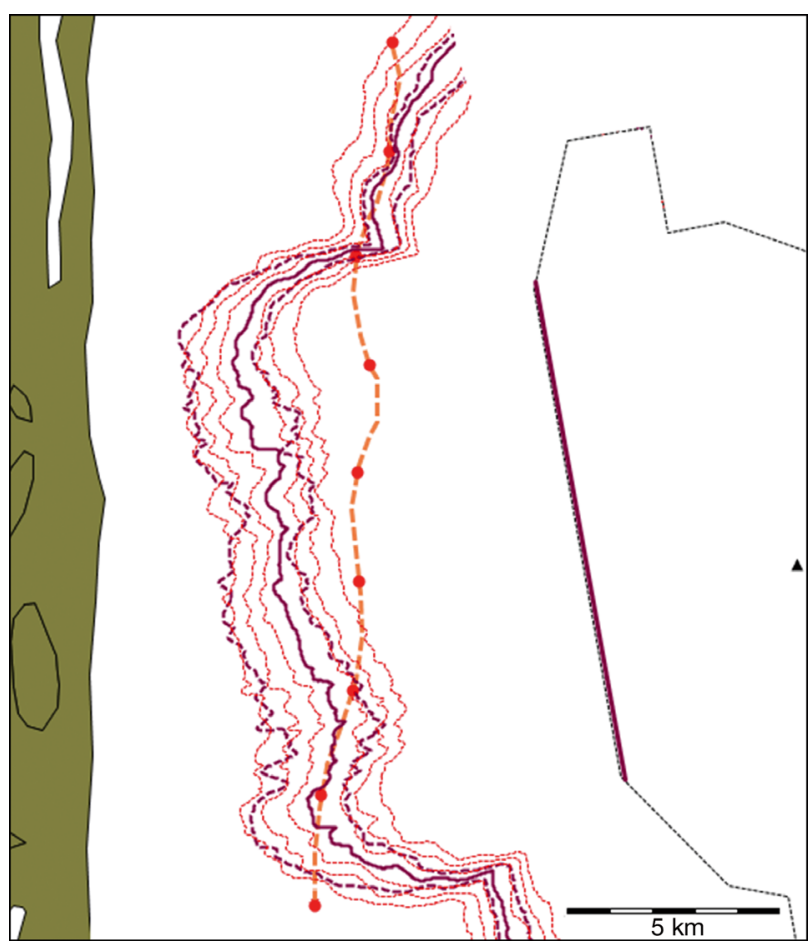

Fig. 3. Behavioural protection zone boundaries for the most near-shore survey line under base (solid purple line), low and high propagation regimes (dashed purple lines) infilled by finer level adjustments in $1 \mathrm{~dB}$ sound exposure level steps (thin red lines). Orange dashed line: PML; red dots: T-AUARs; black triangle: PA-A platform; solid line: most western A-line in seismic survey area

full length of the survey line, but only when the northern part of a line was acquired. We determined from acoustic modelling the most southern location for each line where an A-zone would begin, and applied a $500 \mathrm{~m}$ buffer margin southward of this point to define the transition point where the specific mitigation measures designed for A-lines took effect (Fig. 4). South of the transition point, less stringent Bline mitigation measures were applied (for precautionary reasons an exception was made for the 3 seismic lines nearest to the feeding grounds, which were always treated as full A-lines). The yellow areas in Fig. 2 depict the area covered by the partial A-lines under default propagation conditions. The rationale behind the definition of partial A-lines was to avoid unnecessary application of the more restrictive mitigation measures associated with the presence of an A-zone, thus facilitating the completion of the survey as early in the season as possible. Once the vessel was past the transition point, A-zone-specific mitigation measures were applied independent of the position of the seismic source in relation to an observed gray whale in the A-zone. Animals located in the A- 


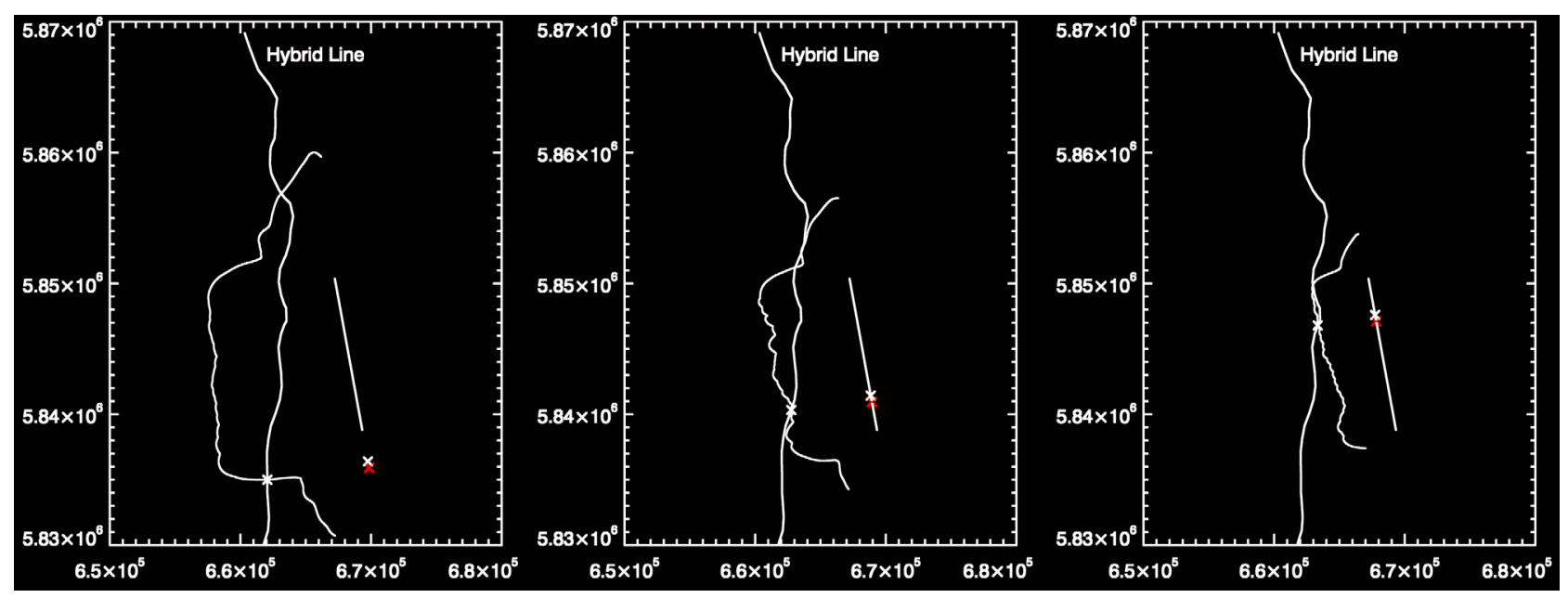

Fig. 4. Examples of 3 model cases for Line 1, i.e. the most near-shore line. Left: propagation conditions high, $+5 \mathrm{~dB}$ offset; middle: propagation conditions base, $0 \mathrm{~dB}$ offset; right: propagation conditions low, $-5 \mathrm{~dB}$ offset. The white $\mathrm{X}$ to the left in each panel indicates the beginning of the A-zone with corresponding position of the seismic vessel (white $\mathrm{X}$ to the right in each panel). The red X includes the $500 \mathrm{~m}$ safety margin, i.e. shut-down is required from this point onwards upon observation of whales in the A-zone

zone, but north or south of the seismic vessel, would not necessarily be exposed to pulse levels $>156 \mathrm{~dB}$ SEL, as sound levels were highest on the broadside beam of the airgun array (Racca et al. 2012b). Their detection would trigger a shut-down nevertheless, making the statically defined A-zone a precautionary mitigation strategy.

\section{Acoustic monitoring configuration}

A $20 \mathrm{~km}$ segment of the feeding area boundary adjacent to the seismic survey area was designated as the PML. A network of 9 Telemetered Autonomous Underwater Acoustic Recorders (T-AUARs) was deployed along the PML (Fig. 2), with the objective of real-time verification of the accuracy of the acoustic modelling results determining the classification of A-versus B-lines, and the shape of the A-zone for A-lines (Rutenko et al. 2012a). The T-AUAR digital acoustic recorders (16 bit, $30 \mathrm{kHz}$ sample rate to internal hard drive) were installed at $2.5 \mathrm{~km}$ intervals on the sea floor, with radio telemetry of a subsampled waveform $(\sim 4 \mathrm{kHz}$ sample rate) provided via tethered transmitting buoys. Temporary malfunction of a single device was acceptable under the terms of the MMP, but the distance between 2 active T-AUARs had to be no less than $5 \mathrm{~km}$ to ensure accurate realtime verification of modelled results over the full length of the PML. Therefore, no seismic acquisition could take place if 2 adjacent T-AUARs malfunctioned until at least 1 unit was put back into opera- tion. The 9 channels of digital data were transmitted via a VHF link to an acoustic receiving station located at the southern tip of Piltun lagoon (Fig. 2) (Rutenko et al. 2012a). The telemetered data were archived to disk and processed by a front-end computer for spectral characterization, then streamed in $1 \mathrm{~min}$ batches over a local network to an independent system for analysis of airgun array pulse levels and ongoing verification of model estimates throughout the acquisition of each seismic line (Racca et al. 2012a). Additionally, 3 non-telemetric archival acoustic receivers (AUARs) were deployed within the Piltun feeding area on the $10 \mathrm{~m}$ isobath to provide shallow water data for post-operation analysis of the sound field from the seismic survey. In parallel with acoustic monitoring, the coordinates of all vessels operating around the survey area were acquired with an Automatic Identification System (AIS) receiver and displayed on a GIS map for immediate interpretation of the activities and to be logged to disk for future reference.

\section{Model case selection and real-time verification}

The onshore acoustic team would begin logging the received pulse levels from the AUARs on a multichannel display when the seismic vessel reached the start of a line. The pulse levels from the first minute of acquisition at the 3 T-AUARs closest to the line starting point were used for the selection of the best model case for that line run. This was done by comparing 
the average measured pulse levels at the 3 T-AUARs to the predicted levels at the same sites provided by the set of model cases for the active line. The model case that resulted in the smallest residual between the forecast and measured start-of-line levels was selected, which determined the shape and area of the A-zone (Racca et al. in press). The selected model case identifier was broadcast to 3 visual observation teams ( 2 based at tower platforms on the shoreline and 1 on the observation vessel) who then retrieved the corresponding pre-modelled A-zone boundary from a locally stored GIS database. The appropriate A-zone boundary would appear as a map overlay in the specialized cetacean tracking software systems (Pythagoras; Gailey \& Ortega-Ortiz 2002) which processed gray whale observation fixes from theodolites and Whaletrack II (Gailey 2006) which processed estimations from reticle binoculars. Both of these systems produced geo-referenced coordinates of animals overlaid with an A-zone boundary on the same map. This enabled the teams to assess in real-time whether a whale sighting was within or outside the estimated region of the A-zone and react according to the response procedures outlined in the MMP.

The acoustic team used a custom software application to display a real-time chart of the received pulse level traces at all the PML stations as the source vessel progressed along the line. The application screen also allowed a direct comparison between the selected model case and measurement at a given sensor. The active model case was deemed to be in compliance with the MMP directives if the measured pulse level trace remained within a tolerance band of $+3 \mathrm{~dB}$ from the modelled trace. A violation of this condition would have meant that the current A-zone boundary being used by the visual observation teams was no longer applicable and would have to be updated with another model case.

\section{PILTUN-ASTOKH SEISMIC SURVEY MMP: MITIGATION}

\section{Timing and area}

Avoiding or minimizing spatial and/or temporal overlap of anthropogenic activity with marine mammal presence is the most effective means of mitigating the effects of acoustic energy on marine mammals (JNCC 2010). For this reason, the spatial overlap with the feeding area was minimized by reducing the acquisition area of the 2010 survey to $<20 \%$ of the area surveyed in 1997 (from 1000 to $\sim 170 \mathrm{~km}^{2}$ ). This reduction was feasible because the production-related changes that needed to be surveyed occurred only in a subset of the area surveyed in 1997 (LGL 2010). This area reduction also resulted in a substantial decrease in survey duration and cumulative acoustic sound levels.

Limiting factors for acquiring seismic data include (1) the presence of sea ice from December to June, as a totally ice-free sea surface is required for maneuverability of the seismic vessel and its $\sim 6 \mathrm{~km}$ long towed streamers and (2) the generally poor sea states from October to December when severe storms are frequent. The available window to conduct the seismic survey was therefore limited to the period of June through September. The number of gray whales observed on the Piltun feeding grounds is initially low (June to July), with the main influx of animals occurring in August to September (Vladimirov et al. 2013) (Fig. 5). Starting the survey immediately at the time of ice-free conditions, and completing it prior to the arrival of the majority of the population, was the most important mitigation measure of this MMP. To start the survey as soon as the sea ice allowed, historical ice data were examined to determine average ice-free dates. Additionally, in the weeks prior to the survey, satellite data depicting ice development in the Sea of Okhotsk were monitored on a daily basis to fine-tune the earliest starting date as a basis for mobilizing the seismic and support vessels and the field teams. The scheduled duration of the seismic survey was approximately $3 \mathrm{wk}$.

\section{Reduction of source array volume}

Various options for reducing the effective acoustic footprint of the airgun array were considered in the design of the repeat survey, subject to the requirement that the results of the imaging be sufficiently similar to the original 1997 survey to allow their differential (time-lapse) interpretation. The analysis showed that it would be possible to reduce the total volume of the airguns while preserving the necessary spectral similarity of the acoustic output; as a result, the airgun array size was reduced (from 2840 to 2620 cubic inches).

\section{Exclusion zone}

The exclusion zone applied around the seismic array, with the radius determined by the $180 \mathrm{~dB}$ re $1 \mu \mathrm{Pa}$ rms threshold at the broadside maximum, was 

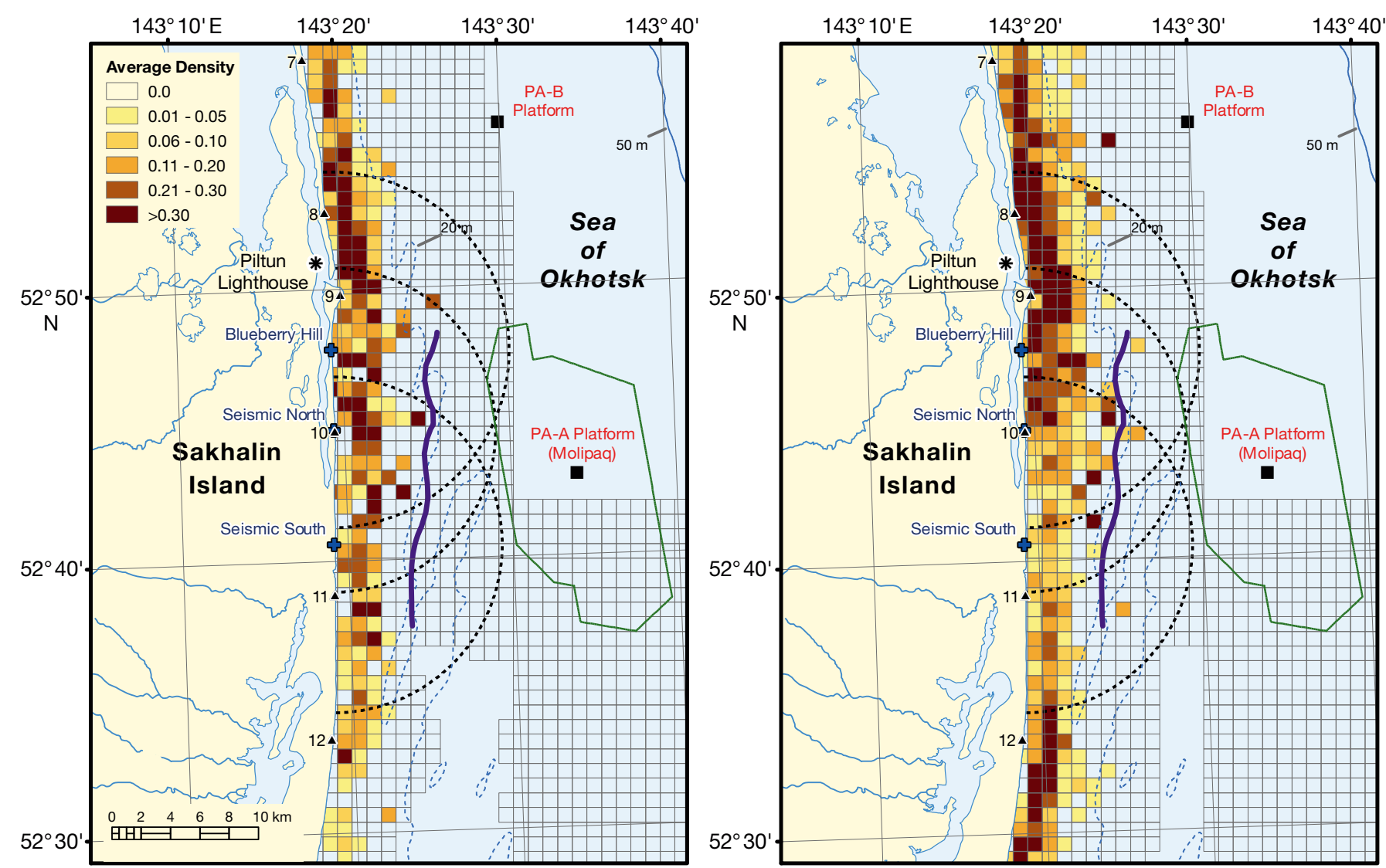

Fig. 5. June to July (left) and August to September (right) average estimated densities of gray whales based on 2005 to 2007 data are shown overlaid with the 2010 seismic survey area (green line). The dotted semicircles provide mean viewing ranges from the 3 behavioural stations ( 0 reticle distance at 0 tide height). The solid blue line represents the perimeter monitoring line. Other symbols as in Fig. 1

consistent with the guidelines of the US National Marine Fisheries Service and the High Energy Seismic Survey team (NOAA 1998, HESS 1999). The alternative single-impulse criterion for the onset of physical injury (198 $\mathrm{dB}$ re $1 \mu \mathrm{Pa}^{2}$-s SEL) (Southall et al. 2007) was considered, but due to the protected status of the whale population, as well as the limited underlying knowledge of hearing frequencies for baleen whales, a precautionary decision was made to apply the $180 \mathrm{~dB}$ re $1 \mu \mathrm{Pa}$ rms criterion (Nowacek et al. 2013). Based on criteria established by the US National Marine Fisheries Service, an exclusion zone with a threshold of $190 \mathrm{~dB}$ re $1 \mu \mathrm{Pa}$ rms was applied for an endangered population of pinnipeds (the Steller sea lion Eumetopias jubatus) known to occur in the area (NMFS 2000).

A sound source verification experiment (SSV) was conducted prior to the start of the seismic survey to determine the distance from the seismic array to the 180 and $190 \mathrm{~dB}$ re $1 \mu \mathrm{Pa}$ thresholds. A precautionary default exclusion zone of $2 \mathrm{~km}$ was applied until the results of the SSV experiment were available. A cau- tionary safety margin of $20 \%$ was to be applied if the exclusion zone based on the SSV turned out to be $<1.7 \mathrm{~km}$, and the exclusion zone radius was prescribed not to be smaller than $1 \mathrm{~km}$.

\section{Visual monitoring of the exclusion zone from the seismic vessel}

Experienced MMOs were placed on all vessels involved in the seismic survey, i.e. the seismic vessel, 2 support vessels and an environmental monitoring vessel. On the seismic vessel 'Pacific Explorer', 2 observers were on duty at any given time $20 \mathrm{~min}$ before ramp-up, during ramp-up and during acquisition, to monitor the exclusion zone for the presence of marine mammals. To prevent observer fatigue, shifts were limited to a maximum $2 \mathrm{~h}$ continuously on watch with a minimum of $1 \mathrm{~h}$ between shifts. The lead MMO on the Pacific Explorer had the authority to request shut-down of the airguns immediately upon observing cetaceans or Steller sea lions to enter 
the 180 and $190 \mathrm{~dB}$ re $1 \mu \mathrm{Pa}$ rms exclusion zones, respectively. A precautionary shut-down was also implemented if any of these marine mammals were observed to be on course to enter the exclusion zones.

\section{Behaviour shut-down criteria for gray whales}

In addition to the exclusion zones applied to prevent auditory injury, shut-down criteria were implemented for gray whales observed within the identified A-zone and thus potentially exposed to sound levels >156 dB SEL that could trigger behavioural responses. Shut-downs were also implemented when an animal was observed to display aberrant behaviour outside the A-zone. This was defined as a consistently high speed of travel $\left(>10 \mathrm{~km} \mathrm{~h}^{-1}\right)$, mothercalf pair separation of $>5$ body lengths, or repeated multiple breaching (i.e. leaping above the sea surface) with correspondingly high speeds of movement away from a potential source of disturbance. When visibility deteriorated to the extent that the Azone could not be monitored effectively during acquisition of A-lines, a shut-down was ordered. The same applied for the exclusion zone around the seismic vessel if the line had not been scouted in the previous $6 \mathrm{~h}$.

\section{Pre-shooting search}

Following Joint Nature Conservation Committee (JNCC) recommendations, MMOs conducted a preshooting survey of the exclusion zone for $20 \mathrm{~min}$ prior to the start of ramp-up (JNCC 2010). No ramp-up was initiated if whales were seen in the exclusion zone during this period.

\section{Ramp-up}

After any period of seismic source inactivity longer than 20 min, a ramp-up procedure was implemented over the course of at least 20 min. Ramp-up was initiated with the smallest airgun (20 cubic inches) with progressively larger gun combinations being activated at regular intervals, resulting in approximately $6 \mathrm{~dB}$ increments. Although broadly, but not universally, accepted as effective, the objective of ramp-up is to prevent animals from being exposed to abrupt increases in sound levels and give them an opportunity to move away from the seismic array prior to full- power operation. The seismic array was shut down if cetaceans or Steller sea lions were observed in the exclusion zone or were judged likely to enter it during ramp-up.

\section{Line changes}

The airgun array was completely shut down during line changes, which took approximately $3 \mathrm{~h}$. In early planning it had been intended to operate the smallest airgun ( 328 $\left.\mathrm{cm}^{3}\left[20 \mathrm{in}^{3}\right]\right)$ during line changes to deter marine mammals away from the seismic vessel (cf. 'ramp-up'). This mitigation measure, however, was not included by the company in the final MMP for various reasons: its effectiveness was considered undemonstrated, it would have introduced additional acoustic energy into the marine environment, and it was considered impractical for technical reasons as line turns were used to depressurize and service the airgun arrays. A pre-shooting search and ramp-up procedure were instead conducted prior to the acquisition of each line.

\section{Monitoring requirements during acquisition}

The A-zone was monitored by 2 onshore behaviour teams and a vessel-based team for the presence of gray whales prior to and during acquisition of Alines. If gray whales were observed within the Azone prior to the start of a line, seismic acquisition would be delayed by $6 \mathrm{~h}$; that period would be lengthened to $12 \mathrm{~h}$ if cow-calf pairs were observed. A-lines were not acquired at night or when insufficient visibility prevented effective monitoring of the entire A-zone.

B-lines could be acquired at night or during poor weather conditions, on the condition that the entire line was scouted for the presence of cetaceans during the preceding $6 \mathrm{~h}$ (during the survey a maximum of $6 \mathrm{~h}$ darkness per $24 \mathrm{~h}$ cycle was anticipated). Scanning was conducted by MMOs either from the scout vessel or from the seismic vessel whilst sailing an adjacent line (lines were spaced approximately $300 \mathrm{~m}$ apart). The JNCC guidelines recommend the use of Passive Acoustic Monitoring (PAM) whilst shooting at night or in poor visibility (JNCC 2010). The use of PAM was not considered beneficial, however, because gray whale vocalizations have rarely been detected during the course of acoustic monitoring programs conducted on the near-shore feeding grounds since 2002 (Borisov et al. 2012). 


\section{Independent observer}

An observer, designated by the WGWAP, independently reported on the implementation of the monitoring and mitigation measures (Hurley 2010). The observer was stationed on shore to observe monitoring teams and the central command center. Although the observer was only present during the first part of the survey, he concluded that the MMP was implemented successfully and that it appeared efficient in protecting a population of whales from harmful exposure to seismic sound (Hurley 2010).

\section{PILTUN-ASTOKH SEISMIC SURVEY MMP: MONITORING}

\section{Behavioural monitoring}

Two shore-based teams conducted behavioural monitoring prior to the start of the seismic survey (2 wk), during the seismic survey and after completion of the survey ( $2 \mathrm{wk}$ ). To maximize the observation range, monitoring was conducted from two $3 \mathrm{~m}$ high wooden towers, i.e. one for the southern and one for the northern section of the zone (Fig. 5). Due to the increasing number of whales in the northern part of the survey area towards the end of the seismic survey, an ad hoc observation station ('Blueberry Hill') was established north of the 2 towers to provide optimal coverage of the northern part of the A-zone. The southern station provided poor coverage of the southern part of the A-zone during acquisition of the most eastern Alines, and the behavioural station Blueberry Hill was used instead on $2 \mathrm{~d}$ towards the end of the seismic survey. Apart from monitoring the A-zone for the presence of whales during acquisition of A-lines, a second objective of the behavioural teams was to determine if seismic activity and/or vessel proximity affected the behaviour of animals within the A-zone (Gailey et al. in press). Consistent with previous behavioural monitoring during industrial activities in the Piltun area, univariate and multivariate analyses were conducted to assess the null hypothesis of no behavioural effects caused by continuous and/or pulse sounds and/or proximity of vessels during the 4D seismic survey (Gailey et al. 2007a,b, in press, Johnson et al. 2007). The 2 behavioural teams conducted 3 types of observations: (1) regular scans to determine distribution and abundance of gray whales, (2) focal-animal follows to monitor respiration patterns and (3) theodolite tracking to obtain geographic positions of the whales over time. The teams operated independently of one another apart from the theodolite tracking. Focalanimal follows and theodolite tracking data were used to derive 9 movement and 7 respiration response variables. Behavioural data were consistent with those previously employed for behavioural monitoring of gray whales on the Piltun feeding grounds (Gailey et al. 2011).

\section{Environmental monitoring vessel}

The monitoring vessel 'Pavel Gordienko' supported the onshore behavioural and acoustic teams in various ways. The vessel had the facilities required to function as a back-up acoustic receiving station in case of malfunction of the onshore station. A vesselbased behavioural team provided assistance to the onshore behavioural teams by monitoring the A-zone from the east (seaward) side of the PML. During seismic acquisition of A-lines the environmental monitoring vessel would advance about $1 \mathrm{~km}$ in front of the seismic vessel and $1 \mathrm{~km}$ east of the PML to scan the feeding grounds for the presence of gray whales. This monitoring routine would change when gray whales were observed in or near the A-zone, at which time the vessel would take a stationary position to continue monitoring the location of the whale. When no A-lines were being acquired, the vessel-based behavioural team would conduct focal follows of gray whales.

\section{Distribution monitoring}

As part of a multi-disciplinary gray whale study program off Sakhalin, distribution and abundance in the Piltun feeding area have been studied on an annual basis since 2002 from a total of 13 onshore distribution stations located along $\sim 110 \mathrm{~km}$ of coastline (Vladimirov et al. 2013). Multiple distribution surveys were performed daily, weather permitting, within the southern Piltun feeding area before, during and after the 2010 4D Piltun-Astokh seismic survey activity. The survey objectives were to monitor gray whale distribution and abundance and to collect data for postsurvey analyses of the potential influence of seismic activity on gray whale distribution and abundance (Muir et al. in press $a, b$ ). A survey, consisting of a set of scans at the 5 southern distribution stations by 2 teams, was conducted before, during and after every seismic line acquisition, weather permitting. As the duration of a line-turn did not typically allow both a post- and pre-survey for the next line, a single survey was usually performed during the line-turn. Surveys 
were spaced throughout the day, weather permitting, during pre- and post-seismic monitoring. A third team conducted daily surveys at the other 8 distribution stations north of the mouth of the Piltun lagoon (Distribution Stns 1 to 8), independent of seismic activity. Data from the northern team were collected to monitor distribution and abundance of gray whales before, during and after the seismic survey, but was not used for further analysis.

A summary of all mitigation and monitoring measures is provided in Table 1.

\section{PILTUN-ASTOKH SEISMIC SURVEY MMP: IMPLEMENTATION}

\section{Execution of the seismic survey}

Onshore behavioural and distribution teams were mobilized on 30 May to conduct pre-seismic scans when some sea ice was still present; they demobilized on 13 July after completing post-seismic surveys. Weather conditions during the pre-seismic and seismic periods were generally favorable for visual observations. As expected, the number of whales in the survey area was very low up to the first week of seismic activity and gradually increased as the field season progressed. Although scheduled, effective onshore monitoring during the post-seismic period was precluded by poor weather conditions.

The environmental monitoring vessel 'Pavel Gordienko' arrived in the Piltun area on 5 June, conducted systematic distribution surveys on 7 and 8 June, and deployed the archival and telemetry-based acoustic recorders on 8 June. The recorders were retrieved upon completion of the seismic survey.

The seismic survey vessel 'Pacific Explorer' arrived in the survey area in the early morning of 9 June. After it had scouted the survey area for the presence of sea ice and satellite data had been analyzed, the region was declared ice free later that day. Deployment of the streamers and airgun array was completed by 12 June. The start of the survey, however, was delayed until 18 June due to technical issues related to rigging of the streamers and malfunctioning of the airguns in the cold water temperatures. The seismic survey was completed on 2 July. The line acquisition time for the 35 lines ranged between 1.26 and $2.80 \mathrm{~h}$, depending on currents, vessel speed and length of line. The minimum time required for a line turn was $2.75 \mathrm{~h}$ and was largely determined by currents, length of the streamers, servicing of the airgun array and ramp-up procedures (Table 2).

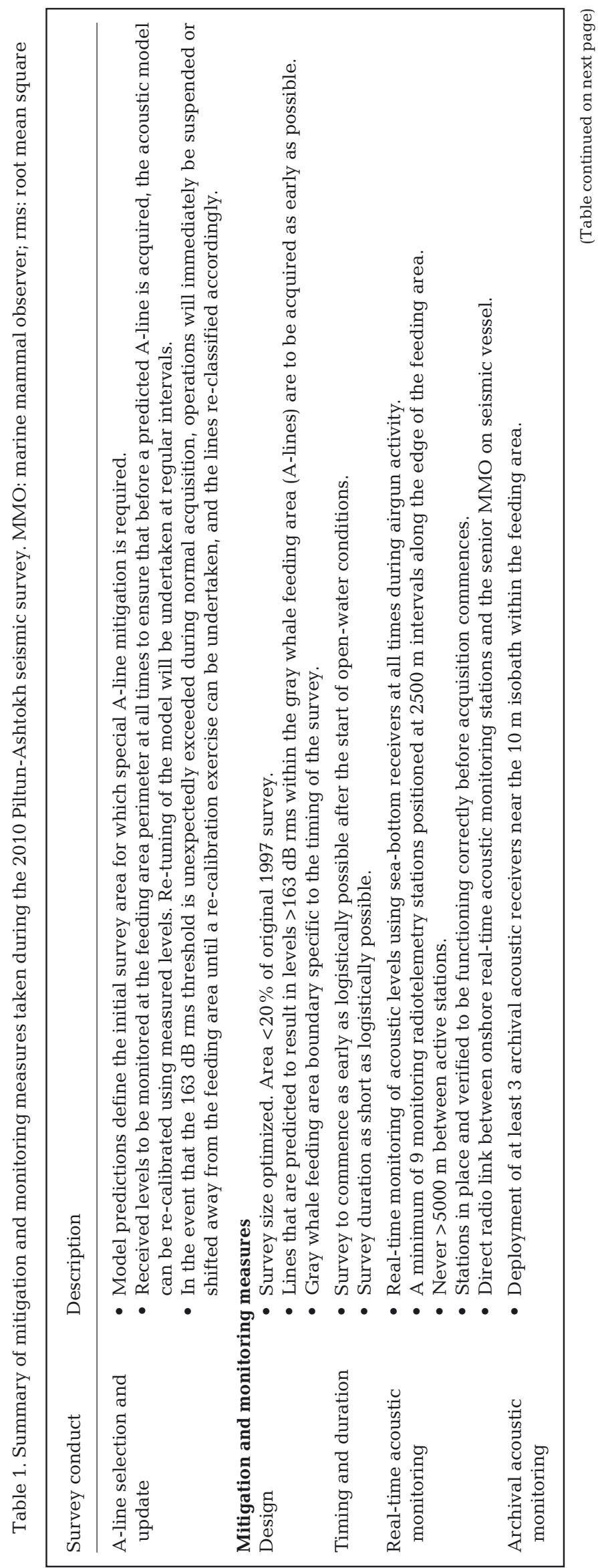




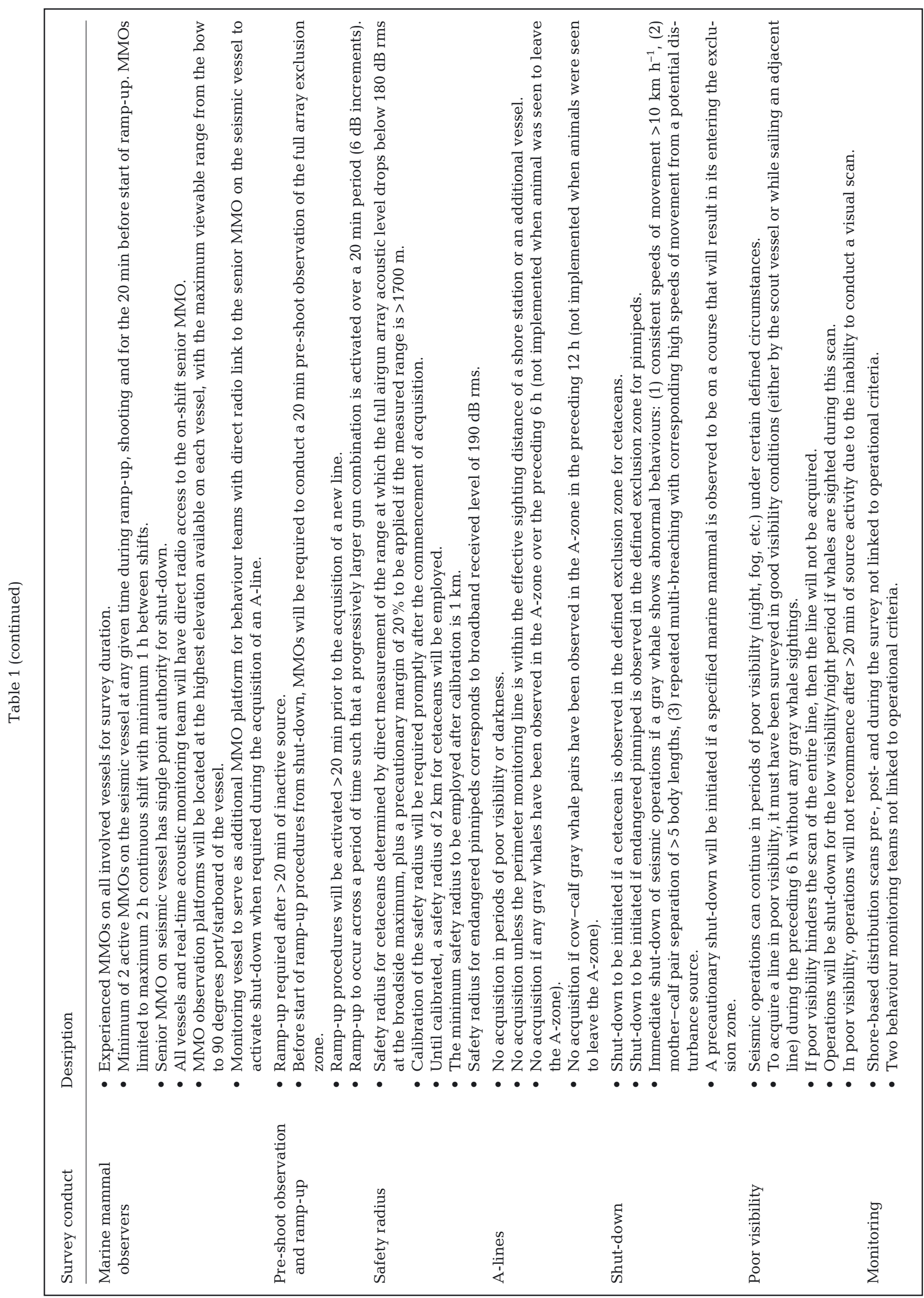


Due to lateral drag caused by tidal currents, seismic streamers are often not positioned in a straight line behind the seismic vessel but rather form small angles relative to the tow axis, a condition known as feathering. Due to the repeated nature of this survey, with requirements to precisely match earlier acquisition conditions, feathering of the streamers had to be within 3 degrees of that encountered during the 1997 survey. On 10 occasions, the amount of feathering exceeded the maximum tolerable discrepancy, resulting in the requirement to abort and/or re-acquire the lines.

\section{Execution of the monitoring and mitigation plan}

Most monitoring and mitigation measures were successfully implemented (Hurley 2010, IUCN 2010c). However, technical issues that delayed the start of the

Table 2. Seismic line acquisition register (date/time is Greenwich mean time $+11 \mathrm{~h}$ ). Line cat. (category) A: lines that could ensonify the delineated feeding grounds at sound levels greater than the $156 \mathrm{~dB}$ SEL behavioural threshold; Line category B: the remaining seismic lines at farther distances from the feeding grounds; Line compl.: line completed; Data quality: Data quality sufficient; Tech: Technical issue; Vis: poor visibility Y: yes; N: no. Dates are given as dd/mm/yy

\begin{tabular}{|c|c|c|c|c|c|c|c|c|c|c|c|c|}
\hline Line & $\begin{array}{l}\text { Line } \\
\text { cat. }\end{array}$ & Date & $\begin{array}{l}\text { Start } \\
\text { ramp-up } \\
\text { (hh:mm) }\end{array}$ & $\begin{array}{c}\text { Start } \\
\text { time } \\
\text { (hh:mm) }\end{array}$ & $\begin{array}{c}\text { End } \\
\text { time } \\
\text { (hh:mm) }\end{array}$ & $\begin{array}{l}\text { Dur- } \\
\text { ation } \\
\text { (h:mm) }\end{array}$ & $\begin{array}{l}\text { Line } \\
\text { compl. }\end{array}$ & $\begin{array}{l}\text { Data } \\
\text { quality }\end{array}$ & $\begin{array}{l}\text { Reasor } \\
\text { Tech. }\end{array}$ & $\begin{array}{l}\text { for shut- } \\
\text { Whales }\end{array}$ & $\begin{array}{l}\text { down } \\
\text { Vis. }\end{array}$ & Comments \\
\hline 33 & B & $16 / 06 / 10$ & $23: 10$ & $23: 56$ & $00: 46$ & $0: 50$ & $\mathrm{~N}$ & $\mathrm{~N}$ & Y & & & \\
\hline 33 & B & $17 / 06 / 10$ & $23: 15$ & 00:03 & 01:39 & $1: 36$ & $\mathrm{~N}$ & $\mathrm{~N}$ & $\mathrm{Y}$ & & & \\
\hline 11 & A & $18 / 06 / 10$ & $05: 15$ & 06:03 & $08: 48$ & $2: 45$ & $\mathrm{Y}$ & $\mathrm{Y}$ & & & & \\
\hline 23 & B & $18 / 06 / 10$ & $10: 45$ & 11:18 & $13: 39$ & $2: 21$ & $\mathrm{Y}$ & $\mathrm{Y}$ & & & & \\
\hline 32 & B & $18 / 06 / 10$ & $22: 02$ & $22: 45$ & $00: 41$ & $1: 56$ & $\mathrm{Y}$ & $\mathrm{Y}$ & & & & \\
\hline 25 & B & $19 / 06 / 10$ & $05: 40$ & $06: 16$ & $07: 58$ & $1: 42$ & $\mathrm{Y}$ & $\mathrm{Y}$ & & & & \\
\hline 2 & $\mathrm{~A}$ & $19 / 06 / 10$ & 09:35 & $10: 04$ & $11: 51$ & $1: 47$ & $\mathrm{Y}$ & $\mathrm{Y}$ & & & & \\
\hline 28 & B & $19 / 06 / 10$ & $13: 42$ & $14: 16$ & $16: 27$ & $2: 11$ & $\mathrm{Y}$ & $\mathrm{N}$ & & & & \\
\hline 6 & A & 19/06/10 & $18: 20$ & $19: 03$ & $19: 08$ & 0:05 & $\mathrm{N}$ & $\mathrm{N}$ & & & $\mathrm{Y}$ & $\begin{array}{l}\text { Fog: insufficient visibility to observe } \\
\text { A-zone \& exclusion zone }\end{array}$ \\
\hline 29 & B & $19 / 06 / 10$ & $22: 07$ & $22: 46$ & $00: 54$ & $2: 08$ & $\mathrm{Y}$ & $\mathrm{Y}$ & & & & \\
\hline 31 & B & $20 / 06 / 10$ & $20: 26$ & $21: 25$ & $23: 27$ & $2: 02$ & $\mathrm{Y}$ & $\mathrm{Y}$ & & & & \\
\hline 22 & B & $21 / 06 / 10$ & $04: 15$ & 05:00 & 05:02 & 0:02 & $\mathrm{N}$ & $\mathrm{N}$ & & & $\mathrm{Y}$ & $\begin{array}{l}\text { Fog: insufficient visibility to monitor } \\
\text { exclusion zone }\end{array}$ \\
\hline 24 & B & $21 / 06 / 10$ & $11: 22$ & $12: 06$ & $14: 11$ & 2:05 & $\mathrm{Y}$ & $\mathrm{N}$ & $\mathrm{Y}$ & & & Airgun misfiring \\
\hline 30 & B & $21 / 06 / 10$ & $21: 22$ & $22: 05$ & 00:00 & $1: 55$ & $\mathrm{Y}$ & $\mathrm{N}$ & $\mathrm{Y}$ & & & Airgun misfiring \\
\hline 26 & B & $22 / 06 / 10$ & $11: 50$ & $12: 33$ & $14: 43$ & $2: 10$ & $\mathrm{Y}$ & $\mathrm{Y}$ & & & & \\
\hline 12 & $\mathrm{~A}$ & $22 / 06 / 10$ & $16: 00$ & $16: 48$ & $17: 34$ & $0: 46$ & $\mathrm{~N}$ & $\mathrm{~N}$ & & & $\mathrm{Y}$ & $\begin{array}{l}\text { Fog: insufficient visibility to monitor } \\
\text { A-zone }\end{array}$ \\
\hline 33 & B & $22 / 06 / 10$ & $20: 19$ & $21: 06$ & $22: 44$ & $1: 38$ & $\mathrm{Y}$ & $\mathrm{Y}$ & & & & \\
\hline 21 & B & $23 / 06 / 10$ & $08: 30$ & 09:08 & $11: 38$ & $2: 30$ & $\mathrm{Y}$ & $\mathrm{Y}$ & & & & \\
\hline 1 & A & $23 / 06 / 10$ & $13: 25$ & $14: 06$ & $15: 22$ & $1: 16$ & $\mathrm{Y}$ & $\mathrm{Y}$ & & & & \\
\hline $23 \mathrm{~A}$ & B & $23 / 06 / 10$ & $16: 51$ & $17: 35$ & $19: 35$ & $2: 00$ & $\mathrm{Y}$ & $\mathrm{Y}$ & & & & \\
\hline 24 & B & $24 / 06 / 10$ & $01: 20$ & 01:48 & $03: 38$ & $1: 50$ & $\mathrm{Y}$ & $\mathrm{N}$ & $\mathrm{Y}$ & & & Airgun misfiring \\
\hline 30 & B & $24 / 06 / 10$ & $08: 40$ & 09:19 & $11: 31$ & $2: 12$ & $\mathrm{Y}$ & $\mathrm{Y}$ & & & & \\
\hline 6 & $\mathrm{~A}$ & $24 / 06 / 10$ & $13: 26$ & $13: 59$ & $14: 43$ & $0: 44$ & $\mathrm{~N}$ & $\mathrm{Y}$ & & $\mathrm{Y}$ & & Whale in A-zone \\
\hline $12 \mathrm{~A}$ & $\mathrm{~A}$ & $24 / 06 / 10$ & $18: 00$ & $18: 48$ & $20: 43$ & $1: 55$ & $\mathrm{Y}$ & $\mathrm{Y}$ & & & & \\
\hline 14 & B & $25 / 06 / 10$ & $03: 35$ & $04: 03$ & $06: 08$ & $2: 05$ & $\mathrm{Y}$ & $\mathrm{Y}$ & & & & \\
\hline 6 & $\mathrm{~A}$ & $25 / 06 / 10$ & $11: 35$ & $12: 04$ & $12: 38$ & $0: 34$ & $\mathrm{~N}$ & $\mathrm{Y}$ & & & $\mathrm{Y}$ & $\begin{array}{l}\text { Fog: insufficient visibility to monitor } \\
\text { A-zone; shut-down at transition point }\end{array}$ \\
\hline 12 & A & $25 / 06 / 10$ & $20: 35$ & 21:05 & $22: 56$ & $1: 51$ & $\mathrm{~N}$ & $\mathrm{Y}$ & & & & $\begin{array}{l}\text { Scheduled shut-down: line could not } \\
\text { be completed as night time prevent- } \\
\text { ed the A-zone from being monitored }\end{array}$ \\
\hline 15 & B & $26 / 06 / 10$ & 02:05 & 02:31 & $04: 21$ & $1: 50$ & $\mathrm{Y}$ & $\mathrm{Y}$ & & & & \\
\hline 4 & A & $26 / 06 / 10$ & $06: 15$ & $06: 43$ & $7: 13$ & $0: 30$ & $\mathrm{~N}$ & $\mathrm{Y}$ & & $\mathrm{Y}$ & & $\begin{array}{l}\text { Whales in A-zone: shut-down at } \\
\text { transition point }\end{array}$ \\
\hline 28 & B & $26 / 06 / 10$ & $10: 18$ & $10: 47$ & $13: 03$ & $2: 16$ & $\mathrm{Y}$ & $\mathrm{Y}$ & & & & \\
\hline 5 & $\mathrm{~A}$ & $26 / 06 / 10$ & $14: 35$ & $15: 02$ & $16: 50$ & $1: 48$ & $\mathrm{Y}$ & $\mathrm{Y}$ & & & & \\
\hline 13 & B & $26 / 06 / 10$ & $18: 50$ & $19: 15$ & $21: 15$ & 2:00 & $\mathrm{Y}$ & $\mathrm{Y}$ & & & & \\
\hline 17 & B & $27 / 06 / 10$ & $03: 35$ & 04:05 & $04: 43$ & $0: 38$ & $\mathrm{~N}$ & $\mathrm{Y}$ & & & & Section north of Molikpaq \\
\hline 3 & $\mathrm{~A}$ & $27 / 06 / 10$ & $07: 25$ & $07: 52$ & $09: 24$ & $1: 32$ & $\mathrm{Y}$ & $\mathrm{Y}$ & & & & \\
\hline 27 & B & $27 / 06 / 10$ & $11: 07$ & $11: 40$ & $14: 18$ & $2: 38$ & $\mathrm{Y}$ & $\mathrm{N}$ & & & & Issue with data recording \\
\hline
\end{tabular}


Table 2 (continued)

\begin{tabular}{|c|c|c|c|c|c|c|c|c|c|c|c|}
\hline Line & $\begin{array}{l}\text { Line } \\
\text { cat. }\end{array}$ & Date & $\begin{array}{l}\text { Start } \\
\text { ramp-up } \\
\text { (hh:mm) }\end{array}$ & $\begin{array}{c}\text { Start } \\
\text { time } \\
(\mathrm{hh}: \mathrm{mm})\end{array}$ & $\begin{array}{l}\text { End } \\
\text { time } \\
\text { (hh:mm) }\end{array}$ & $\begin{array}{l}\text { Dur- } \\
\text { ation } \\
(\mathrm{h}: \mathrm{mm})\end{array}$ & $\begin{array}{l}\text { Line } \\
\text { compl. }\end{array}$ & $\begin{array}{l}\text { Data } \\
\text { quality }\end{array}$ & $\begin{array}{c}\text { Reason } \\
\text { Tech. }\end{array}$ & $\begin{array}{l}\text { for shut-down } \\
\text { Whales Vis. }\end{array}$ & Comments \\
\hline 7 & A & $27 / 06 / 10$ & $18: 19$ & $18: 46$ & 19:16 & $0: 30$ & $\mathrm{~N}$ & $\mathrm{Y}$ & & $\mathrm{Y}$ & $\begin{array}{l}\text { Whale north of seismic vessel dis- } \\
\text { played aberrant behaviour (breaching) }\end{array}$ \\
\hline 16 & $\mathrm{~B}$ & $27 / 06 / 10$ & $22: 46$ & $23: 16$ & $23: 46$ & $0: 30$ & $\mathrm{~N}$ & $\mathrm{~N}$ & $\mathrm{Y}$ & & Poor feather match \\
\hline 9 & $\mathrm{~A}$ & $28 / 06 / 10$ & $05: 47$ & $06: 13$ & $08: 31$ & $2: 18$ & $\mathrm{Y}$ & $\mathrm{Y}$ & & & \\
\hline 22 & B & 28/06/10 & $10: 45$ & $11: 21$ & $14: 09$ & $2: 48$ & $\mathrm{Y}$ & $\mathrm{Y}$ & & & \\
\hline 6 & $\mathrm{~A}$ & $28 / 06 / 10$ & $15: 47$ & $16: 26$ & $17: 33$ & $1: 07$ & $\mathrm{Y}$ & $\mathrm{Y}$ & & & \\
\hline 17 & B & $28 / 06 / 10$ & $20: 18$ & $20: 56$ & $21: 47$ & $0: 51$ & $\mathrm{Y}$ & $\mathrm{N}$ & $\mathrm{Y}$ & & $\begin{array}{l}\text { Poor feather match; section south of } \\
\text { Molikpaq }\end{array}$ \\
\hline 10 & $\mathrm{~A}$ & $29 / 06 / 10$ & $05: 51$ & $06: 29$ & $08: 49$ & $2: 20$ & $\mathrm{Y}$ & $\mathrm{Y}$ & & & \\
\hline 20 & B & $29 / 06 / 10$ & $11: 12$ & $11: 51$ & $14: 37$ & $2: 46$ & $\mathrm{Y}$ & $\mathrm{Y}$ & & & \\
\hline 4 & $\mathrm{~A}$ & $29 / 06 / 10$ & $18: 45$ & $19: 22$ & $20: 46$ & $1: 24$ & $\mathrm{~N}$ & $\mathrm{Y}$ & & $\mathrm{Y}$ & Whales observed in the A-zone \\
\hline 16 & $\mathrm{~B}$ & $29 / 06 / 10$ & $23: 20$ & $23: 55$ & $01: 38$ & $1: 43$ & $\mathrm{Y}$ & $\mathrm{Y}$ & & & \\
\hline 12 & $\mathrm{~A}$ & $30 / 06 / 10$ & $05: 30$ & 06:00 & $06: 55$ & $0: 55$ & $\mathrm{Y}$ & $\mathrm{Y}$ & & & \\
\hline 19 & $\mathrm{~B}$ & $30 / 06 / 10$ & 09:06 & 09:46 & $10: 16$ & $0: 30$ & $\mathrm{~N}$ & $\mathrm{Y}$ & $\mathrm{Y}$ & & Poor feather match \\
\hline 27 & $\mathrm{~B}$ & $30 / 06 / 10$ & $13: 15$ & $13: 55$ & $16: 22$ & $2: 27$ & $\mathrm{Y}$ & $\mathrm{Y}$ & & & \\
\hline 4 & A & $30 / 06 / 10$ & $21: 05$ & $21: 44$ & $22: 17$ & $0: 33$ & $\mathrm{Y}$ & $\mathrm{Y}$ & & & \\
\hline 17 & $\mathrm{~B}$ & $01 / 07 / 10$ & $01: 20$ & 01:59 & 02:40 & $0: 41$ & $\mathrm{Y}$ & $\mathrm{Y}$ & & & Section south of Molikpaq \\
\hline 7 & $\mathrm{~A}$ & $01 / 07 / 10$ & $06: 20$ & $06: 50$ & 09:08 & $2: 18$ & $\mathrm{Y}$ & $\mathrm{Y}$ & & & \\
\hline 18 & $\mathrm{~B}$ & $01 / 07 / 10$ & $12: 10$ & $12: 49$ & $15: 23$ & $2: 34$ & $\mathrm{Y}$ & $\mathrm{N}$ & $\mathrm{Y}$ & & Poor feather match \\
\hline 8 & $\mathrm{~A}$ & 01/07/10 & $22: 10$ & $22: 58$ & $00: 33$ & $1: 35$ & $\mathrm{~N}$ & $\mathrm{Y}$ & & & $\begin{array}{l}\text { Scheduled shut-down: line could not } \\
\text { be completed as night time prevented } \\
\text { the A-zone from being monitored }\end{array}$ \\
\hline 18 & $\mathrm{~B}$ & 02/07/10 & $03: 24$ & 04:06 & $04: 46$ & $0: 40$ & $\mathrm{Y}$ & $\mathrm{Y}$ & & & \\
\hline 8 & $\mathrm{~A}$ & 02/07/10 & $08: 30$ & $08: 56$ & 09:52 & $0: 56$ & $\mathrm{Y}$ & $\mathrm{Y}$ & & & \\
\hline 19 & B & 02/07/10 & $12: 55$ & $13: 36$ & $16: 13$ & $2: 37$ & $\mathrm{Y}$ & $\mathrm{Y}$ & & & \\
\hline
\end{tabular}

seismic survey, poor visibility, and increasing numbers of whales throughout the course of the operation made implementation of the MMP challenging. These issues could have prolonged the duration of the seismic survey considerably. Two alterations to the MMP were made during the execution phase of the plan to facilitate timely completion of the survey. Firstly, the rule preventing the acquisition of a seismic line if any gray whales were observed in the A-zone over the preceding $6 \mathrm{~h}$ (or $12 \mathrm{~h}$ for cow-calf pairs) was bypassed if the whales in the A-zone were observed to move outside this zone before the beginning of line acquisition. This was deemed justifiable as these whales would no longer be at risk of being exposed to sound levels exceeding $156 \mathrm{~dB}$ SEL. Secondly, the acquisition of a partial A-line up to the transition point was allowed to take place at night or in poor visibility if that line had been scouted in the previous $6 \mathrm{~h}$, in keeping with the conditions applicable to full B-lines. Given that the pre-transition segment of a partial Aline did not generate an A-zone, this was considered acceptable since animals on the feeding grounds would not be exposed to sound levels above the behavioural criterion. Both alterations were implemented as they were not considered by the SSTF to weaken the effectiveness of the mitigation program.

\section{Sound source verification}

The sound source verification test was conducted on 16 and 17 June during acquisition of test lines. Mini-AUARs were deployed at $0.75,1.5$ and $3 \mathrm{~km}$ from the most eastern seismic line, and recorded sound levels at the closest point of approach. The $180 \mathrm{~dB}$ re $1 \mu \mathrm{Pa}$ received level threshold was calculated to be $1.22 \mathrm{~km}$ away from the array. A $20 \%$ precautionary margin resulted in an exclusion radius of $1.46 \mathrm{~km}$, which was rounded up to $1.5 \mathrm{~km}$. The $190 \mathrm{~dB}$ re $1 \mu \mathrm{Pa}$ exclusion threshold for endangered pinnipeds was determined to occur at $540 \mathrm{~m}$ from the array (Racca et al. in press).

\section{Implementation of marine mammal shut-down criteria}

A total of 9 marine mammal-related seismic source shut-downs were ordered. Their causes were: presence of whales in the exclusion zone (1 case), presence of gray whales in the A-zone during acquisition of A-lines (3 cases), display of aberrant behaviour by a gray whale (1 case) and inability to continue monitoring the A-zone and/or exclusion 
zone due to poor visibility (4 cases). These occurrences are summarized in Table 2 and described in more detail below.

A shut-down was implemented on 1 occasion during ramp-up due to the presence of a common minke whale Balaenoptera acutorostrata within the exclusion zone. No other shut-downs occurred during seismic acquisition as a result of gray whales, other cetaceans, or Steller sea lions being observed within the exclusion zone. A shut-down was ordered in 3 cases when gray whales were observed within the Azone during A-line acquisition. A single breach was observed during 1 of these events. A gray whale was observed to breach multiple times in the A-zone during seismic acquisition. The received sound levels at the whale's location were below the behavioural threshold ( 140 dB $1 \mu \mathrm{Pa}$ rms) as the animal was positioned several kilometres north of the seismic vessel. It is not clear whether this behaviour was in some way a response to the seismic survey or the monitoring vessel, which was at least $1 \mathrm{~km}$ away from the animal, but, because multiple breaching was classified as aberrant behaviour in the MMP, a shut-down was implemented accordingly. In 3 cases, acquisition of Alines had to be aborted due to insufficient visibility (fog) to effectively monitor the A-zone. During acquisition of a B-line, the visibility deteriorated so that the exclusion zone could not be effectively monitored. As the line had not been scouted in the previous $6 \mathrm{~h}$, a shut-down was implemented. In addition to these 9 whale-related shut-downs, the southern part of 2 Alines was acquired at night up to the transition point, at which the airguns were shut down. As these shutdowns were a result of implementation of the MMP, they were categorized as 'darkness standby' (Table 3).

\section{Time budget of MMP}

Table 3 outlines the seismic vessel's ('Pacific Explorer') activities. Mobilization issues from 13 to 18 June resulted in a 5 d delay ( $\sim 25 \%$ of the total vessel time). The categories 'whale standby', 'fog standby' and 'darkness standby' were considered delays as a result of implementing the MMP. The MMP added $3.7 \mathrm{~d}$ to the survey duration $(19 \%$ of the total vessel time). However, relatively few whales were in the area at the onset of the survey period, and very few fog days occurred from 13 to 18 June. Therefore, the standby time due to fog and the presence of whales would have decreased if the survey had started on the original starting date (13 June) instead of being delayed by technical issues.
Table 3. Time breakdown of 'Pacific Explorer' activities in the period 13 June to 2 July 2010

\begin{tabular}{|lcc|}
\hline Activity & Days & Percent \\
\hline Acquisition & 3.4 & 17.1 \\
Line change & 3.6 & 18.1 \\
Obstruction standby & 0.1 & 0.7 \\
Whale standby & 0.6 & 3.3 \\
Fog standby & 1.8 & 9.3 \\
Currents/feathering & 1.8 & 8.9 \\
Darkness standby & 1.3 & 6.4 \\
Mobilization issues & 5.0 & 25.4 \\
Other & 2.1 & 10.9 \\
Total & 19.7 & 100 \\
\hline
\end{tabular}

\section{PILTUN-ASTOKH SEISMIC SURVEY MMP: EFFECTIVENESS}

\section{Estimation of sound levels on whale paths}

One objective of the MMP was to obtain a better understanding of the impacts of pulsed and continuous noise on gray whale behaviour. To that end, the variables that may affect whale behaviour must be quantified at the whale locations. During the survey, positional information was collected for numerous whale paths by 2 behavioural monitoring teams, and the locations of all vessels in the immediate area were recorded by AIS/GPS logging. From these data it was possible to model sound levels from the airgun source and vessels as received at the whale locations. This estimation process yielded detailed time histories of sound levels at whale locations for all recorded whale tracks. Fig. 6 provides an example of sound level exposure of a gray whale during the seismic survey. These data were used to assess behavioural responses on an individual level, as well as on a population level (Gailey et al. in press). Further details on sound level estimations at whale locations and analyses of behavioural responses during these tracks are provided in Racca et al. (in press) and Gailey et al. (in press), respectively.

\section{Impact of seismic sounds on gray whale distribution and behaviour}

Focal-animal follow and theodolite tracking data were analyzed by assessing movement and respiration response variables relative to acoustic metrics, environmental, temporal, spatial and behavioural information, as well as vessel sound levels and distances, to investigate disturbance effects of seismic activity in the proximity of the near-shore feeding habitat of gray whales. 


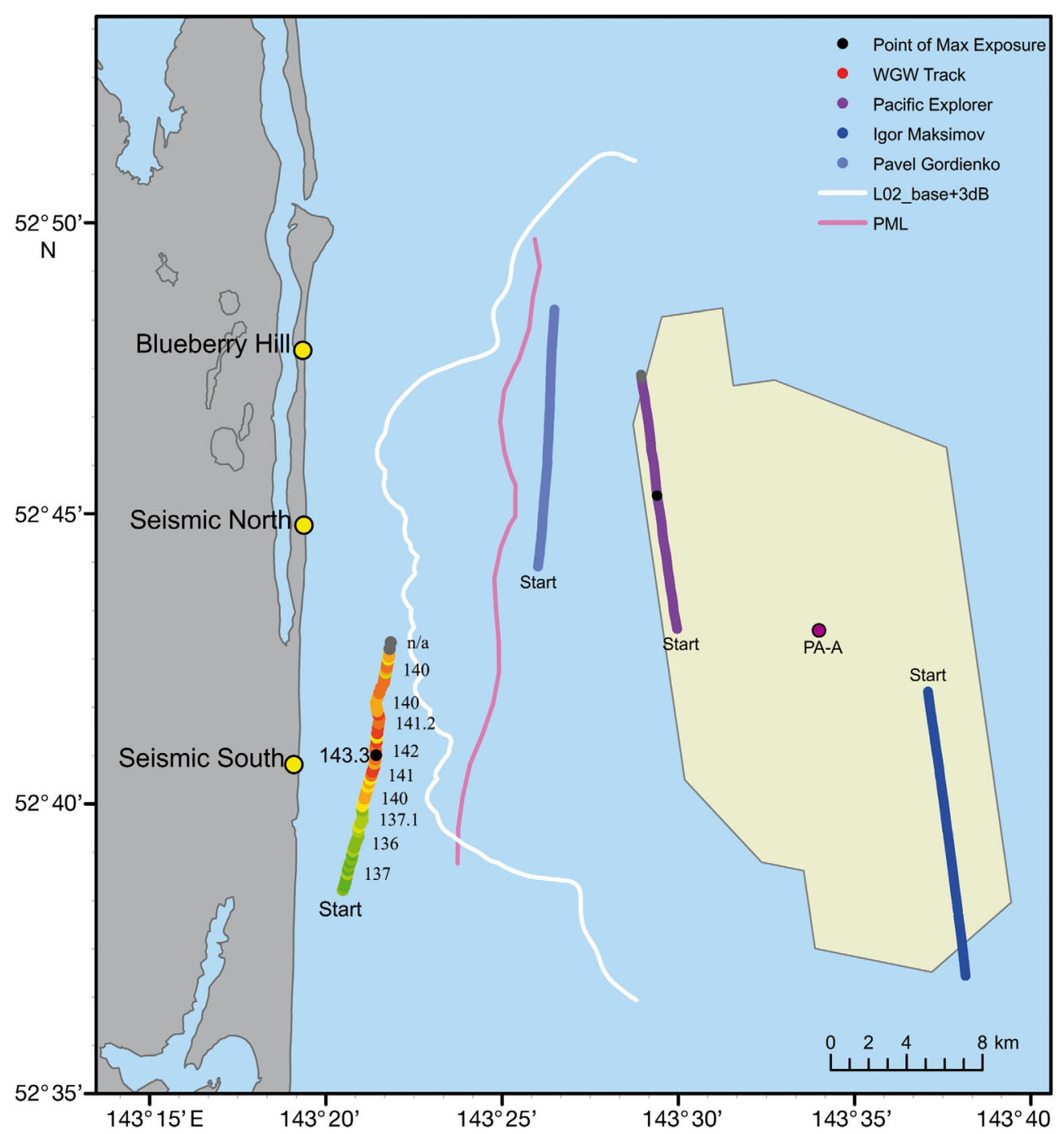

Fig. 6. Gray whale path annotated with estimated received sound levels (per-pulse SEL) from the seismic source acquiring a survey line. The track of the source vessel 'Pacific Explorer' for the same time period is shown in purple at the nearshore edge of the seismic survey area (yellow). The corresponding track of the monitoring vessel 'Pavel Gordienko' is shown in lighter blue near the perimeter monitoring line (PML), and that of the scout vessel 'Igor Maksimov' in darker blue near the offshore edge of the survey region. The simultaneous start points of the tracks are labelled, and black dots indicate the relative locations of source and whale at time of maximum exposure. Shown on shore are 3 behavioural monitoring stations

While seismic sounds were not significantly associated with movement and respiration parameters on a population level, a number of behavioural response variables were associated with the proximity of vessels, suggesting some level of a non-seismic anthropogenic effect (Gailey et al. in press). Power analyses demonstrated the study's ability to detect large effects $(>50 \%)$, but not to identify more moderate or subtle changes in respiration and movement (Gailey et al. in press). Although some individual responses in movement patterns were observed, the results from the behavioural analysis suggested the seismic survey did not have a large impact on the movement or respiration patterns of the population of gray whales as a whole (Gailey et al. in press).

Two separate distribution analyses were conducted to investigate cumulative sound exposure from seismic activity relative to changes in both sighting distance from shore and in mean daily gray whale density surfaces of $1 \times 1 \mathrm{~km}$ grid cells. No significant effects of cumulative sound on distance from shore were observed (Muir et al. in press b). However, higher cumulative sound levels in the previous 24 to $48 \mathrm{~h}$ were associated with slightly decreased grid cell densities, and models predicted slightly higher occupancy probabilities in the northern part of the study 
area that corresponded to moderate cumulative seismic sound levels (Muir et al. in press a). These effects of cumulative sound from the seismic activity on occupancy and densities suggest avoidance of higher cumulative sound exposure levels associated with a prolonged period of acoustic disturbance (Muir et al. in press a). As pointed out by Muir et al. (in press a), a limitation of the distribution analyses was that data on prey abundance were not available; therefore, this important predictor of whale distribution was not included in the models.

The main mitigation measure of completing the survey as early in the feeding season as possible was relatively successful, but inevitably resulted in reduced power to assess the impacts of seismic sound exposure on gray whale distribution and behaviour. Few whales were present, particularly during the preseismic period and the first week of the seismic survey. This resulted in relatively few observations to compare with those made during the seismic period, and limited the ability to assess potential changes in distribution and behaviour relative to seismic sound exposure. Analyses were further limited by poor weather conditions in the post-seismic survey monitoring period that resulted in nearly no survey effort, and limited statistical power to compare whale distribution and behaviour during and after the seismic survey activity.

In terms of population consequences, important observations are that the body condition of animals appeared to have improved over the 2010 feeding period, with only $11.1 \%$ of the observed individuals having 'low' body condition scores at the last sighting of the 2010 feeding season compared to a mean $( \pm$ SD) of $14.3 \pm 4.64$ from 2002 to 2012 (Tyurneva et al. 2013). The seismic survey is not thought to have affected calf production, an important population parameter, judging by the fact that 15 calves were sighted in 2011 (the highest number over the period 2001 to 2012) and 9 in 2012 (Tyurneva et al. 2012, 2013).

These analyses were extensively discussed during various SSTF meetings (IUCN 2010a,b,c, 2011). The SSTF strove to evaluate the implementation and effectiveness of applied mitigation measures, and recognized the largely satisfactory field enactment of the MMP.

\section{FINDINGS AND RECOMMENDATIONS}

(1) Careful planning in development and implementation of the MMP by a multi-disciplinary techni- cal team of both independent and company-contracted scientists led to an effective plan that appears to have met the objective of reducing risks to gray whales from the seismic survey (IUCN 2010c, Nowacek et al. 2013). As explained, the objective of obtaining insight into the potential impacts of future seismic surveys could be met only partially, because of the overarching mitigation imperative of completing the work before substantial numbers of whales arrived at the feeding grounds (see Item 5 below).

(2) Implementation of this MMP was logistically and technically challenging, as it involved several vessels, multiple shore- and vessel-based monitoring teams, various channels of communication and critical reliance on technical equipment in a remote environment.

(3) Future MMPs developed for gray whales on the Piltun feeding grounds should incorporate into the shut-down criteria behavioural observations of animals prior to approaching or entering the A-zone. Given that the primary objective was to minimize disruptions to feeding activity, animals observed as simply traversing the habitat even within the A-zone and not displaying aberrant behaviour should not be considered in determining the requirements for shut-down, since this may lengthen the survey unnecessarily.

(4) Although the shape of the A-zone was different for each A-line, the A-zone used in this MMP was static, in the sense that it was independent of the location of the seismic source in relation to the position of an observed whale. Animals in the A-zone were not necessarily exposed to sound levels exceeding $156 \mathrm{~dB}$ SEL if they were sufficiently far to the north or south of the seismic vessel at the time. Due to the directionality of the seismic array, the highest sound levels were generated broadside to the source, thus creating a relatively narrow envelope of sound exposure abeam the vessel. A dynamic A-zone could be applied instead, encompassing the broadside beam of the source with a buffer distance fore and aft of the seismic vessel. This buffer would have to be sufficiently large to prevent animals from being exposed to pulse levels exceeding $156 \mathrm{~dB}$ SEL, but could still reduce the duration of the survey by eliminating unnecessary shut-downs for animals far enough ahead of or behind the seismic vessel.

(5) Due to the relatively short duration and completion of the survey early in the feeding season, when the number of gray whales in the area was still low, relatively few visual observations were made of individuals exposed to seismic pulses. Furthermore, observations in the period following the seismic survey were limited due to poor weather conditions. 
These factors reduced the statistical power to detect changes in whale behaviour and distribution in relation to seismic activity. An enhanced understanding of data requirements and analytical approaches, obtained through additional power analyses during the MMP development phase, would help improve the design of the monitoring program to support meaningful conclusions.

(6) Use of the independent observer gave implementation of the MMP credibility, i.e. interested stakeholders were provided with an independent means of assessing the challenges and effectiveness of implementation.

(7) Limited behavioural or distributional responses of whales to seismic sound exposure were observed, suggesting that the mitigation program for this particular seismic survey was successful in minimizing the impacts on gray whales. However, various kinds of industrial activity take place in or near the Piltun feeding grounds, and successful mitigation of 1 particular event, such as the 2010 Astokh 4D seismic survey, is not adequate by itself. The potential effects of those other activities need to be assessed and managed to minimize the cumulative disturbance to the whale population. A case in point is another seismic survey that was conducted in the Piltun region during the 2010 feeding season by Rosneft Shelf Far East, which acquired seismic data in the Lebedinsky license area (SakhalinV project). Although some mitigation and monitoring measures reportedly were applied, this seismic survey was conducted in the littoral region and within the near-shore feeding grounds when the abundance of gray whales was at its peak (Rutenko et al. 2012b). The cumulative effects of industrial activities on the gray whale population are not well understood, in part due to the general difficulty of assessing impacts of multiple and aggregate stressors on wild populations. The development of frameworks for cumulative impact assessment is an area of active research (example Moore et al. 2012).

\section{CONCLUSIONS}

The 2010 Piltun-Astokh seismic survey ranks as one of the most extensively mitigated marine seismic surveys to date (Nowacek et al. 2013). Though some adjustments to the MMP were introduced in the field to address operational circumstances, the primary mitigation measures were successfully implemented. This seismic survey was exceptional in some ways because of its close proximity to a spatially limited, near-shore feeding area of a Critically Endangered population of whales that could be monitored from shore. Although elements of this MMP can be replicated in other situations, including offshore seismic surveys, there are likely to be few opportunities to implement an identical plan elsewhere. Indeed, most seismic surveys may not warrant the application of a behavioural mitigation threshold unless endangered or threatened populations or species inhabit the region.

Although some whale responses to seismic sound exposure, in the form of small changes in distribution patterns, were detected in the post-season analysis of collected data, the biological significance of such changes on the local population of whales was likely to be minimal.

Acknowledgements. We thank IUCN (F. Larsen) and the Seismic Survey Task Force members of the WGWAP (J. Cooke, G. Donovan, D. Nowacek, R. Reeves, B. Southall, G. Tsidulko, A. Vedenev, D. Weller) for their partnership in development of the MMP, and B. Hurley for providing a constructive assessment of its implementation. This project would not have been possible without the tireless efforts of the distribution teams (N. Doroshenko, P. Marchenko, D. Samarin, A. Samarina, R. Sidorenko, S. Starodymov, M. Starodymova, A. Tishchuk, O. Tomilov), behavioural teams (A. Ermoshin, A. Filipiechev, A. Kalachev, D. Kovshov, I. Krupin, S. Piwetz O. Sychenko, P. Zakharenko), acoustic teams (M. Austin, S. Borisov, D. Borovoy, V. Gritsenko, D. Kozel, V. Likhatchev, A. Rutenko, A. Soloviev, V. Sosnin, N. Tchichov, A. Tischuk, V. Uschipovsky, P. Zakharenko), Marine Mammal Observers, logistics teams and camp support staff. Sakhalin Energy and contractors were helpful in development and implementation of the MMP (D. Bell, M. Angelatos, M. Boekholt, V. Efremov, R. Evans, R. Larin, I. Rosenberger, E. Tijdens, S. Turin, D. Terwogt, B. Tibbles, P. vd.Wolf, I. Zhmaev). The journal 'Aquatic Mammals' provided permission for use of Fig. 2. This manuscript was improved by the thoughtful comments of G. Donovan, R. Reeves and 3 anonymous reviewers. K. Williams (JASCO Applied Sciences) assisted with review of the literature list. This study was funded by Sakhalin Energy Investment Company.

\section{LITERATURE CITED}

Anonymous (2001) Krasnaya Kniga Rossiiskoi Federatsii. (Russian Red Data Book, Volume 1, Animals) Institute of Ecology and Evolution. A. N. Severtsova RAS, Moscow (in Russian). Available at: www.biodat.ru/db/rb/index. htm (accessed 13 May 2014)

Australian Government, Department of the Environment, Water, Heritage and the Arts (2008) EPBC Act Policy Statement 2.1-Interaction between offshore seismic exploration and whales. Department of the Environment, Canberra

Bickham J, Dupont J, Bröker K (2013) Review of the status of the western North Pacific gray whale: stock structure hypotheses, and recommendations for methods of future genetic studies. Paper SC-65a-BRG16 presented to the IWC Scientific Committee. Available at: https://archive. iwc.int/?r=4805 (accessed 4 May 2015) 
Blackwell SB, Nations CS, McDonald TL, Greene CR, Thode AM, Guerra M, Macrander AM (2013) Effects of airgun sounds on bowhead whale calling rates in the Alaskan Beaufort Sea. Mar Mamm Sci 29:342-365

Borisov SV, Borovoy DI, Gritsenko VA, Rutenko AN, Sosnin VA, Ushipovsky VG (2012) Acoustic \& hydrographic studies on the North East Sakhalin Shelf, 27th July to 5th October, 2010. Sakhalin Island, Russian Federation. Prepared for Exxon Neftegas Ltd and Sakhalin Energy Investment Company, Yuzhno-Sakhalinsk. Available at: www.sakhalinenergy.ru/media/0aadefff-c71e-4f2e9773-04b46c0ab36e.pdf (accessed 13 May 2013)

> Bradford AL, Weller DW, Punt AE, Ivashchenko YV, Burdin AM, VanBlaricom GR, Brownell RL Jr (2012) Leaner leviathans: body condition variation in a critically endangered whale population. J Mammal 93:251-266

Collins MD, Cederberg RJ, King DB, Chin-Bing SA (1996) Comparison of algorithms for solving parabolic wave equations. J Acoust Soc Am 100:178-182

Cooke JG, Weller DW, Bradford AL, Sychenko O, Burdin AM, Brownell RL Jr (2013) Population assessment of Sakhalin gray whale aggregation. Paper SC/65a/BRG27 presented to the IWC Scientific Committee. Available at: https://archive.iwc.int/?r=4794 (accessed 1 June 2014)

Fadeev VI (2011) Benthos studies in feeding grounds of the Okhotsk-Korean gray whale population in 2010. In: Western gray whale research and monitoring program in 2010, Sakhalin Island, Russian Federation. Vol II: Results and discussion, Chap 3. Prepared for Exxon Neftegas Ltd and Sakhalin Energy Investment Company, Yuzhno-Sakhalinsk. Available at: www.sakhalinenergy.ru/media/9cd08f6a374e-4811-8fd1-40432d653adc.pdf (accessed 7 June 2014)

> Finneran JJ, Schlundt CE, Dear R, Carder DA, Ridgway SH (2002) Temporary shift in masked hearing thresholds (MTTS) in odontocetes after exposure to single underwater impulses from a seismic watergun. J Acoust Soc Am 111:2929-2940

Gailey G (2006) WhaleTrack II: a network system for marine mammal vessel-based observations and passive acoustics monitoring. Oregon State University, Newport, OR

Gailey G, Ortega-Ortiz J (2002) A computer-based system for cetacean theodolite tracking. J Cetacean Res Manag 4: 213-218

Gailey G, Würsig B, McDonald TL (2007a) Abundance, behaviour, and movement patterns of western gray whales in relation to a 3-D seismic survey, Northeast Sakhalin Island, Russia. Environ Monit Assess 134:75-91

Gailey G, McDonald T, Racca R, Sychenko O, Rutenko A, Würsig B (2007b) Influences of underwater sound and near-shore vessel activity on western gray whale behaviour during the installation of a concrete gravity based structure off Sakhalin Island, summer 2005. Prepared for Exxon-Neftegas Ltd and Sakhalin Energy Investment Company, Yuzhno-Sakhalinsk. http://cmsdata.iucn.org/ downloads/wgwap_2_inf_7__mva.pdf

Gailey G, Sychenko O, Würsig B (2011) Patterns of western gray whale behavior, movement, and occurrence off Sakhalin Island, 2010. Chapter 4. In: Western gray whale research and monitoring program in 2010, Sakhalin Island, Russia. Volume II results and discussion. Prepared for Exxon Neftegas Limited and Sakhalin Energy Investment Company Limited, Yuzhno-Sakhalinsk, p 47-4-63. Available at: www.sakhalinenergy.ru/media/ 9cd08f6a-374e-4811-8fd1-40432d653adc.pdf (accessed 7 June 2014)
Gailey G, Sychenko O, McDonald T, Racca R, Rutenko A, Bröker K (in press) Behavioural responses of western gray whales to a 4-D seismic survey off northeastern Sakhalin Island, Russia. Endang Species Res, doi:10.3354/ esr00713*

HESS (1999) High Energy Seismic Survey (HESS) review process and interim operational guidelines for marine surveys offshore Southern California. Report from High Energy Seismic Survey Team for California State Lands Commission and U.S. Minerals Management Service, Camarillo, CA. www.brasil-rounds.gov.br/round7/arquivos _r7/SISMICA_R7/biblio_R7/HESS\%201999\%20Southern \%20California.pdf

Hurley B (2010) Astokh lease area 4-D seismic survey. Independent observer report. IUCN, Gland. Available at: http://cmsdata.iucn.org/downloads/wgwap_9_doc_20_ independent_observer_report.pdf (accessed 8 June 2014)

International Whaling Commission (2014) Report of the workshop on the rangewide review of the population structure and status of North Pacific gray whales. Paper $\mathrm{SC} / 65 \mathrm{~b} / \mathrm{Rep} 08$ presented to the IWC Scientific Committee. Available at: http://cmsdata.iucn.org/downloads/ wgwap_14_inf_3_gw_stock_id_workshop_iwc_sc_65b_ rep08_en_2014.pdf (accessed 9 October 2014)

IUCN (International Union for Conservation of Nature) (2010a) Report of the seismic survey task force at its 5th meeting. IUCN, Gland. Available at: https://cmsdata. iucn.org/downloads/wgwap_5th_seismic_survey_task_ force_meeting_report.pdf (accessed 13 November 2014)

IUCN (2010b) Report of the seismic survey task force at its 6th meeting. IUCN, Gland. Available at: http://cmsdata. iucn.org/downloads/sstf_6_report_final.pdf (accessed 13 November 2014)

IUCN (2010c) Report of the Western Gray Whale Advisory Panel at its 9th meeting. IUCN, Gland. Available at: http://cmsdata.iucn.org/downloads/wgwap_9_report_ final.pdf (accessed 13 November 2014)

IUCN (2011) Report of the seismic survey task force at its 7th meeting. IUCN, Gland. Available at: http://cmsdata.iucn. org/downloads/sstf_7_report_may_2011_.pdf (accessed 13 November 2014)

JNCC (2010) Joint Nature Conservation Committee guidelines for minimising the risk of injury and disturbance to marine mammals from seismic surveys. Available at: https://www.gov.uk/oil-and-gas-offshore-environmentallegislation (accessed 3 August 2011)

Johnson SR, Richardson WJ, Yazvenko SB, Blokhin SA and others (2007) A western gray whale mitigation and monitoring program for a 3-D seismic survey, Sakhalin Island, Russia. Environ Monit Assess 134:1-19

Kastelein RA, Steen N, Gransier R, de Jong CA (2013) Brief behavioural response threshold level of a harbor porpoise (Phocoena phocoena) to an impulsive sound. Aquat Mamm 39:315-323

LGL (2010) Environmental impact assessment of Sakhalin Energy Investment Company's 3-D seismic programme in the Piltun-Astokh Area, Sakhalin Island, Russia. Prepared for Sakhalin Energy Investment Company, Ltd. Available at: www.sakhalinenergy.ru/media/87cb2a5c7946-4993-a173-d5101045cfae.pdf (accessed 8 June 2014)

Lucke K, Siebert U, Lepper PA, Blanchet MA (2009) Temporary threshold shift in masked hearing thresholds in a harbor porpoise (Phocoena phocoena) after exposure to seismic airgun stimuli. J Acoust Soc Am 125:4060-4070 
MacGillivray AO (2006) Acoustic modelling study of seismic airgun noise in Queen Charlotte Basin. MSc dissertation, University of Victoria, Victoria

Malme CI, Würsig B, Bird JE, Tyack P (1986) Behavioural responses of gray whales to industrial noise: feeding observations and predictive modeling. Outer Continental Shelf Environmental Assessment Program, final report of principal investigators. NOAA No. PB-88-249057/XAB, BBN Labs, Cambridge, MA

Malme CI, Würsig B, Bird JE, Tyack P (1988) Observations of feeding gray whale responses to controlled industrial noise exposure. In: Sackinger WM, Jefferies MO, Imm JL, Treacy SD (eds) Vol 2: Port and ocean engineering under Arctic conditions. University of Alaska, Fairbanks, AK, p 55-73

Mate B, Bradford A, Tsidulko G, Vertyankin V, Ilyashenko V (2011) Late feeding season movements of western North Pacific gray whales off Sakhalin Island, Russia and subsequent migration into the eastern North Pacific. Paper SC/63/BRG23 presented to the International Whaling Commission Scientific Committee. Available at: https:// iwc.int/document_516 (accessed 9 June 2013)

Mate BR, Ilyashenko VY, Bradford AL, Vertyankin VV, Tsidulko GA, Rozhnov VV, Irvine LM (2015) Critically endangered western gray whales migrate to the eastern North Pacific. Biol Lett 11:20150071

MMS (2007) Appendix B. Current seismic surveys mitigation measures in the GOM. United States Department of the Interior Minerals Management Service (MMS) Gulf of Mexico (GOM) OCS Region. Available at: www. nmfs.noaa.gov/pr/pdfs/permits/boemre_appendixb.pdf (accessed 9 June 2014)

> Moore SE, Reeves R, Southall B, Ragen T, Suydam R, Clark C (2012) A new framework for assessing the effects of anthropogenic sound on marine mammals in a rapidly changing Arctic. Bioscience 62:289-295

Muir J, Ainsworth L, Racca R, Bychkov Y and others (in press a) Gray whale densities during a seismic survey off Sakhalin Island, Russian Federation. Endang Species Res, doi:10.3354/esr00709*

Muir J, Ainsworth L, Joy R, Racca R and others (in press b) Examination of distance from shore as an indicator of disturbance of gray whales during a seismic survey off Sakhalin Island, Russia. Endang Species Res, doi: 10.3354/esr00701 *

Muir JE, Joy R, Bychkov Y, Bröker K, Gailey G, Vladmirov V, Starodymov S, Yakovlev Y (in press c) Delineation of a coastal gray whale feeding area using opportunistic and systematic survey effort. Endang Species Res, doi: 10.3354/esr00705 *

- New LF, Moretti DJ, Hooker SK, Costa DP, Simmons SE (2013) Using energetic models to investigate the survival and reproduction of beaked whales (family Ziphiidae). PLoS ONE 8:e68725

New LF, Clark JS, Costa DP, Fleishman E and others (2014) Using short-term measures of behaviour to estimate long-term fitness of southern elephant seals. Mar Ecol Prog Ser 496:99-108

NMFS (National Marine Fisheries Service) (2000) Small takes of marine mammals incidental to specified activities; marine seismic reflection data collection in southern California. 65 Fed Reg p 16374-16379. www.federalregister. gov/articles/2000/03/28/00-7611/small-takes-of-marinemammals-incidental-to-specified-activities-marineseismic-reflection-data (28 Mar 2000)
NOAA (National Oceanic and Atmospheric Administration) (1998) Incidental taking of marine mammals; Acoustic harassment. 63 Fed Reg p 40103 (27 Jul 1998). www.gpo. gov/fdsys/pkg/FR-1998-07-27/pdf/98-19991.pdf

Nowacek DP, Thorne LH, Johnston DW, Tyack PL (2007) Responses of cetaceans to anthropogenic noise. Mammal Rev 37:81-115

Nowacek DP, Bröker K, Donovan G, Gailey G and others (2013) Responsible practices for minimizing and monitoring environmental impacts of marine seismic surveys with an emphasis on marine mammals. Aquat Mamm 39:356-377

Racca R, Rutenko A, Bröker K, Austin M (2012a) A line in the water-design and enactment of a closed loop, model based sound level boundary estimation strategy for mitigation of behavioural impacts from a seismic survey. 11th European Conference on Underwater Acoustics 2012, Edinburgh. Proc Inst Acoustics 34, Part 3

Racca R, Rutenko A, Bröker K, Gailey G (2012b) Model based sound level estimation and in-field adjustment for realtime mitigation of behavioural impacts from a seismic survey and post-event evaluation of sound exposure for individual whales. Acoustics 2012 Fremantle: Acoustics, Development and the Environment, Fremantle. www.acoustics.asn.au/conference_proceedings/ AAS2012/papers/p92.pdf

Racca R, Austin M, Rutenko A, Bröker K (in press) Monitoring the western gray whale sound exposure zone and estimating acoustic transmission during a 4-D seismic survey, Sakhalin Island, Russia. Endang Species Res, doi: 10.3354/esr00703*

Reilly SB, Bannister JL, Best PB, Brown M and others (2008) Eschrichtius robustus (western subpopulation). In: IUCN 2013. IUCN Red List of threatened species, Version 2013.2. Available at: www.iucnredlist.org (accessed 16 May 2014)

Rice DW, Wolman AA (1971) The life history and ecology of the gray whale (Eschrichtius robustus). Special Publication of the American Society of Mammalogists 3:1-142

Richardson WJ, Greene CR Jr, Malme CI, Thomson DH (1995) Marine mammals and noise. Academic Press, San Diego, CA

Rutenko AN, Borovoi DI, Gritsenko VA, Petrov PS, Ushchipovskii VG, Boekholt M (2012a) Monitoring the acoustic field of seismic survey pulses in the near-coastal zone. Acoust Phys 58:326-338

> Rutenko AN, Gavrilevskii AV, Kozvel DG, Korotchenko RA, Putov VF, Solov'ev AA (2012b) Monitoring of seismoacoustic signals and anthropogenic noise on the shelf of Sakhalin Island. Acoust Phys 58:210-219

Schlundt CE, Finneran JJ, Branstetter BK, Trickey JS, Bowman V, Jenkins K (2015) Effects of multiple impulses from a seismic air gun on bottlenose dolphin hearing and behavior. J Acoust Soc Am 137, 1634

Southall BL, Bowles AE, Ellison WT, Finneran JJ and others (2007) Marine mammal noise exposure criteria: initial scientific recommendations. Aquat Mamm 33:411-521

Sychenko OA (2011) Western gray whale (Eschrichtius robustus) mother and calf ecology off Sakhalin Island. MSc thesis, Texas A\&M University, College Station, TX

Tyurneva OY, Yakovlev YM, Vertyankin VV (2012) Photographic identification of the western gray whale (Eschrichtius robustus) offshore northeastern Sakhalin and southeastern shore of Kamchatka Peninsula, 2011. Vol II: results and discussion, Chap 2. Prepared for Exxon Neftegas Ltd and Sakhalin Energy Investment Company, Yuzhno-Sakhalinsk 
Tyurneva OY, Yakovlev YM, Vertyankin VV (2013) Photographic identification of the western gray whale (Eschrichtius robustus) offshore northeastern Sakhalin and southeastern shore of Kamchatka Peninsula, 2012. Vol II: results and discussion, Chap 2. Prepared for Exxon Neftegas Ltd and Sakhalin Energy Investment Company, Yuzhno-Sakhalinsk

Urban RJ, Weller D, Tyurneva O, Swartz S and others (2012) Report on the photographic comparison of the western and Mexican gray whale catalogues. Paper SC/64/ BRG13 presented to the IWC Scientific Committee. Available at: http://iwc.int/private/downloads/87trqxvwu 5s8so8wc48ggggos/SC-64-BRG13rev.pdf (accessed 9 June 2014)

Urban RJ, Weller D, Tyurneva O, Swartz S and others (2013) Report on the photographic comparison of the Sakhalin Island and Kamchatka Peninsula with the Mexican gray whale catalogues. SC/65/BRG04 presented to the IWC Scientific Committee. Available at: https://events. iwc.int/index.php/scientific/SC65a/paper/viewFile/217/ 443/SC-65a-BRG04 (accessed 9 June 2014)

Vladimirov VA, Starodymov SP, Kornienko MS (2013) Distribution and abundance of western gray whales in North-

Editorial responsibility: Randall Reeves, Hudson, Quebec, Canada; Greg Donovan, Cambridge, UK east Sakhalin Waters in 2012 (according to shore-based and vessel-based surveys). In: Western gray whale monitoring program in the Northeast Sakhalin Island offshore in 2011, Russian Federation. Vol 2: results and discussion, Chap 1. Prepared for Exxon Neftegas Ltd and Sakhalin Energy Investment Company, Yuzhno-Sakhalinsk

> Weir CR, Dolman SJ (2007) Comparative review of the regional marine mammal mitigation guidelines implemented during industrial seismic surveys, and guidance towards a worldwide standard. J Int Wildl Law Policy 10: $1-27$

Weller DW, Burdin AM, Würsig B, Taylor BL, Brownell RL Jr (2002) The western gray whale: a review of past exploitation, current status and potential threats. J Cetacean Res Manag 4:7-12

Weller DW, Klimek A, Bradford AL, Calambokidis J and others (2012) Movements of gray whales between the western and eastern North Pacific. Endang Species Res 18: 193-199

Yazvenko SB, McDonald TL, Blokhin SA, Johnson SR and others (2007) Distribution of western gray whales during a seismic survey near Sakhalin Island, Russia. Environ Monit Assess 134:45-73

Submitted: December 31, 2013; Accepted: February 5, 2015 Proofs received from author(s): May 5, 2015 